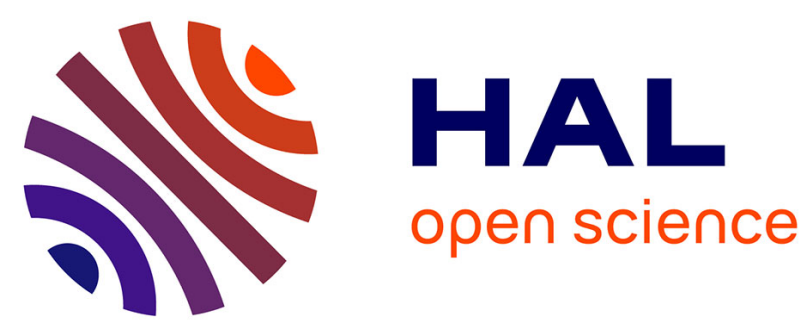

\title{
Green biosorbents based on chitosan-montmorillonite beads for anionic dye removal
}

Francisco a R Pereira, Graycyelle R S Cavalcanti, Líbia N F Queiroga, Ieda M G Santos, Francisco A.R. Pereira, Kaline S Sousa, Graycyelle R.S. Cavalcanti, Denise B França, Líbia N.F. Queiroga, Ieda M.G. Santos, et al.

\section{To cite this version:}

Francisco a R Pereira, Graycyelle R S Cavalcanti, Líbia N F Queiroga, Ieda M G Santos, Francisco A.R. Pereira, et al.. Green biosorbents based on chitosan-montmorillonite beads for anionic dye removal. Journal of Environmental Chemical Engineering, 2017, 5 (4), pp.3309-3318. hal-01955865

\section{HAL Id: hal-01955865 https://hal.sorbonne-universite.fr/hal-01955865}

Submitted on 14 Dec 2018

HAL is a multi-disciplinary open access archive for the deposit and dissemination of scientific research documents, whether they are published or not. The documents may come from teaching and research institutions in France or abroad, or from public or private research centers.
L'archive ouverte pluridisciplinaire HAL, est destinée au dépôt et à la diffusion de documents scientifiques de niveau recherche, publiés ou non, émanant des établissements d'enseignement et de recherche français ou étrangers, des laboratoires publics ou privés. 


\section{Green biosorbents based on chitosan-montmorillonite}

\section{beads for anionic dye removal}

Francisco A.R. Pereira ${ }^{a}$, Kaline S. Sousa ${ }^{b}$, Graycyelle R.S. Cavalcanti ${ }^{\mathrm{b}}$, Denise B. França $^{\mathrm{b}}$, Líbia N.F. Queiroga ${ }^{\mathrm{b}}$, Ieda M.G. Santos ${ }^{\mathrm{b}}$, Maria G. Fonseca ${ }^{\mathrm{b}^{*}}$, Maguy Jaber

${ }^{a}$ Department of Chemistry, Universidade Estadual da Paraíba, UEPB, CEP 58429-500, Campina Grande, PB, Brazil.

${ }^{\mathrm{b}}$ Department of Chemistry, Universidade Federal da Paraíba, UFPB, CEP 58051-900, João Pessoa, PB, Brazil.

${ }^{c}$ Sorbonne Universités, UPMC Paris 6, UMR 8220, Laboratoire d'Archéologie Moléculaire et Structurale, 4 place Jussieu , F-75005 Paris, France

*Corresponding author. Tel: +55-83-3216-7441; fax: +55-83-3216-7433.

E-mail address: mgardennia@quimica.ufpb.br 
Chitosan-KSF composite beads
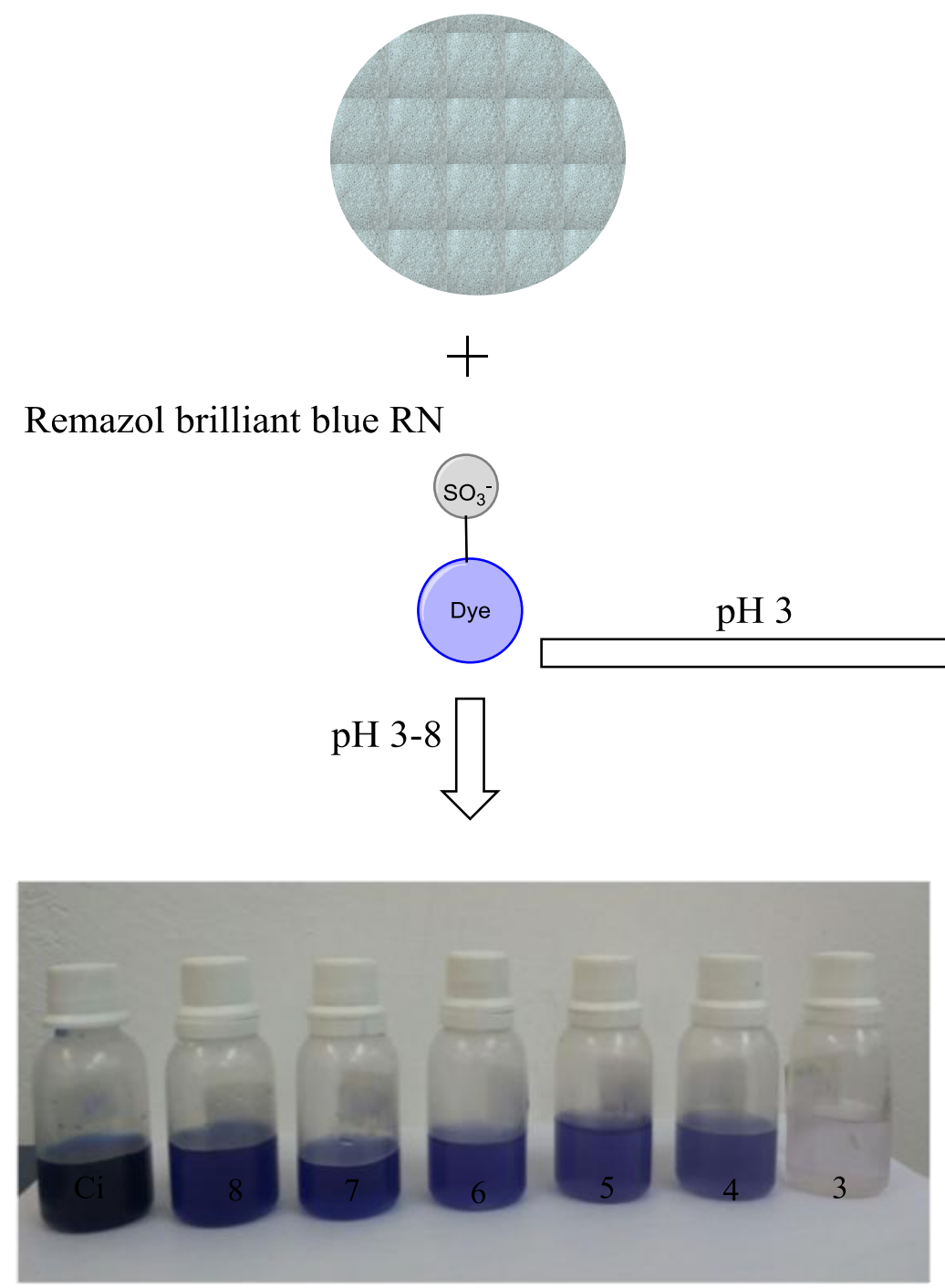

$\mathrm{Ci}=500 \mathrm{mg} / \mathrm{L}$
Chitosan-KSF beads/dye hybrid
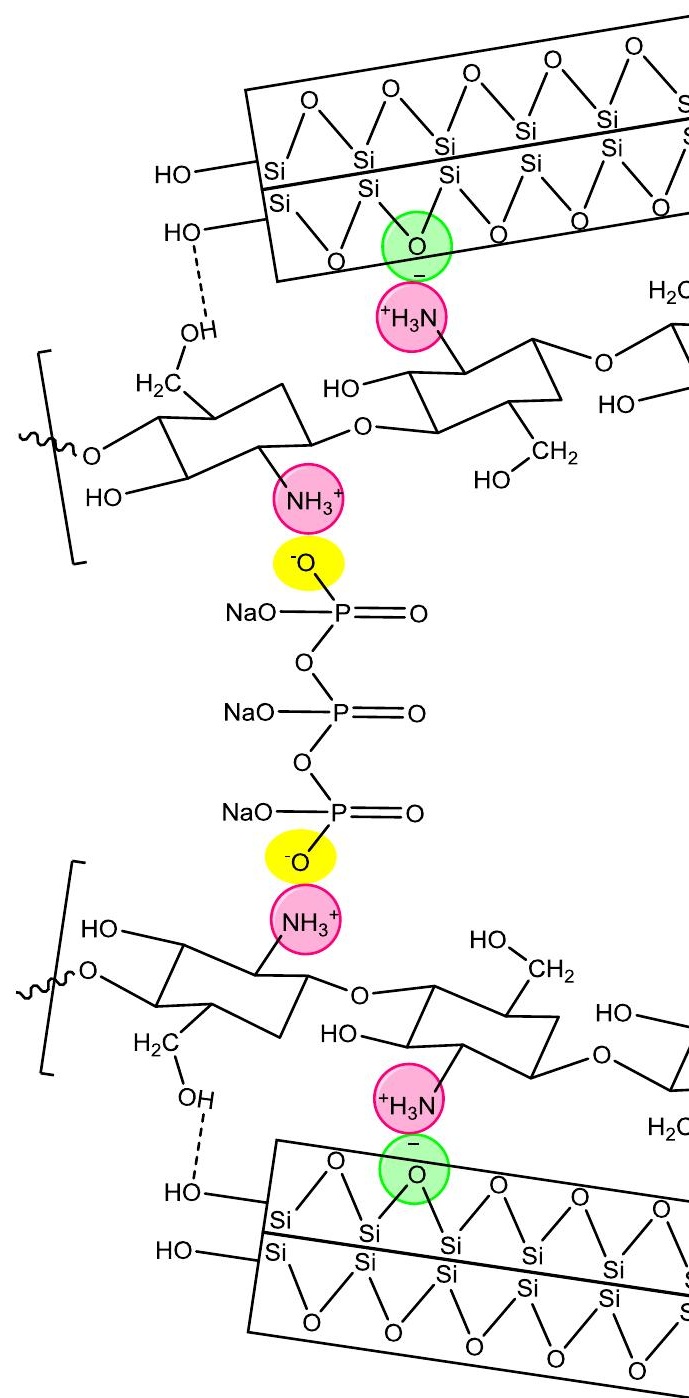

\section{Highlights}

- Chitosan-montmorillonite beads composites were synthesized

- The key parameters that control the adsorption were determined

- Clay mineral stabilized chitosan in acidic medium

- Composites removed anionic dyes in acidic medium

- The dye adsorption mechanism was understood via spectroscopic characterization 


\begin{abstract}
Chitosan/KSF-montmorillonite beads were prepared at $1-25 \% \mathrm{w} / \mathrm{w}$ ratios by reaction of the biopolymer and the clay mineral with sodium tripolyphosphate as crosslinking agent. The synthesized biocomposites were characterized by $\mathrm{CHN}$ elemental analysis, XRD (X-Ray diffraction), FTIR (Fourier transform infrared), ${ }^{13} \mathrm{C}$ NMR (Nuclear magnetic resonance), thermogravimetry, SEM (Scanning electron microscopy), TEM (Transmission electron microscopy) and measurements of point of zero charge $\left(\mathrm{pH}_{\mathrm{pzc}}\right)$. The results suggested that hybrid materials were properly obtained and also their properties were improved compared to the pristine chitosan and montmorillonite. Further, the beads were evaluated in the adsorption of Remazol Blue under batch operations obtained for different conditions at $\mathrm{pH}(2-8)$, contact time (0-660 min) and dye concentration (100-1600 $\left.\mathrm{mg} \mathrm{L}^{-1}\right)$. Kinetic and equilibrium sorption parameters were evaluated using pseudo- first and pseudo-second rate models and Langmuir and Freundlich equations. The results were promising and suggested that the sorbents can be applied for removing anionic dyes from wastewater even in acidic medium.
\end{abstract}

Keywords: Clay minerals; biopolymer; composites; wastewater; organic pollutants 


\section{Introduction}

The presence of dyes in water is a serious environmental problem due their carcinogenic and mutagenic effects on aquatic life and also on human life $[1,2]$.

Dyes generally have a synthetic origin and a complex structure which ensures physico-chemical, thermal and optical stability due the presence of aromatic groups [3]. Therefore, the removal of dyes from waste effluents is widely focused and the various techniques studied, among them adsorption has been shown to be one of the most applicable technologies [4, 5]. Various adsorbents such as clay minerals [6-8] and biopolymers such as chitosan [9] have been used to remove different dyes from wastewater.

Chitosan (CS) is a natural polyaminosaccharide synthesized from the deacetylation of chitin, which is a polysaccharide consisting predominantly of unbranched chains of $\beta$-(1-4)2-acetoamido-2-deoxy-d-glucose [10]. The biopolymer is widely used because of its special characteristics such as abundance in nature, nontoxicity, biocompatibility, biodegradability, hydrophilicity, antimicrobial activity and adsorption properties $[11,12]$. Active sites as amino and hydroxyl groups on CS make it a good candidate to interact with anionic dyes [13]. Electrostatic interactions are reported to be involved in solid/liquid interface between protonated amino functions of the chitosan and the anionic groups of the dyes in solution. As consequence, this biopolymer has been widely studied in the removal of heavy metal cations and organopollutants from wastewater $[14,15]$. However, the use of CS in adsorption is $\mathrm{pH}-$ dependent because it is soluble or form gel under $\mathrm{pH}$ below than 4 [16]. The chemical modification of chitosan and its hybrid derivatives, as crosslinking by tripolyphosphate (TPP) for instance, improve its chemical and mechanical properties [17, 18]. Therefore, the synthesis of based-chitosan composites has presented a new approach to modify 
various properties of this biopolymer, such as swelling/water adsorption [19] and mechanical/thermal performance [20, 21]. In addition, resulting composites have a high rigidity, low specific gravity and a higher resistance to corrosion and oxidation [22].

Various materials have been applied to prepare CS composites such as clay minerals because of their green and simple way of preparation and promising physical and chemical characteristics [23-27]. Among clay minerals, montmorillonite (Mt) is the most used in the smectite group [28, 29]. It is constituted of a hydrous layered aluminum silicate with exchangeable cations and active hydroxyl groups. The nanometer thick layers of Mt consist of aluminum octahedron sheet sandwiched between two silicon tetrahedron sheets. Isomorphic substitution of $\mathrm{Al}^{3+}$ with $\mathrm{Mg}^{2+}$ in the octahedral sheets gives an overall negative charge, which is counterbalanced by cations $\left(\mathrm{Na}^{+}, \mathrm{Ca}^{2+}, \mathrm{Mg}^{2+}\right.$ and $\left.\mathrm{Fe}^{\mathrm{n}+}\right)$ located in the interlayer space [29-32]. Clay minerals are abundant in nature and consequently low cost. Their properties such as the high cation exchange capacity, the possibility of interlayer expansion and the large specific area, may provide greater versatility in the interaction and intercalation of bulky molecules such as CS into Mt [33-39]. Although montmorillonite shows good interaction with cationic dyes [34, 40], it usually displays low affinity for anionic dyes because its negatively charged surface $[41,42]$. Therefore, the montmorillonite modification with polymers changes its physical and chemical properties and improves its affinity for anionic species $[11,27,33]$. However, a toxicological evaluation is always required to avoid potential human and environmental risks. Even though unmodified Mt has been reported to cause low cytotoxicity in many cell lines [43], chitosan/TPP and chitosan/Mt composites has also been described to decrease the toxicity of Mt and to increase some CS properties, such as antimicrobial activity, better cell proliferation and 
biocompatibility [12]. Therefore, the CS-Mt composites are supposed to have very reduced toxicity.

In this perspective, the present investigation aimed to synthesize chitosanmontmorillonite biocomposites beads using TPP as crosslinked agent with Mt w/w ratios of $1,5,15$ and $25 \%$ in order to obtain new adsorbents applicable for Remazol blue removal from aqueous solution. The Remazol blue RN (1-amino-9,10-dioxo-4-[3(2-sulfonatooxietilsulfonil)aniline] anthracene-2-sulfonate, disodium) is an anionic dye widely applied in the textile industry, used as starting material to produce polymeric dyes [44] and is a toxic and recalcitrant organopollutants [45, 46]. The batch operations were evaluated at wide range of experimental conditions to investigate the effects of $\mathrm{pH}$, contact time and the initial dye concentration on the sorption.

\section{Materials and methods}

Montmorillonite-KSF was provided by Sigma-Aldrich, Germany. Chitosan (CS) with an average molecular weight (190-310 kD) and degree of deacetylation (DD) of 78\%, was donated by Primex Company, Iceland. Sodium tripolyphosphate (TPP) used as crosslinker was provided from Sigma-Aldrich, and Remazol Blue (RB, Reactive Blue $19, \mathrm{C}_{22} \mathrm{H}_{16} \mathrm{~N}_{2} \mathrm{Na}_{2} \mathrm{O}_{11} \mathrm{~S}_{3}, \mathrm{M}=626.533 \mathrm{~g} \mathrm{~mol}^{-1}, \mathrm{pKa}=10.2$, Scheme 1) was supplied by the Dye Star Company, Brazil. $\mathrm{NH}_{4} \mathrm{Cl}, \mathrm{NaCl}$, acetic acid and $\mathrm{AgNO}_{3}$ (Vetec) with analytical grade were used without purification. 


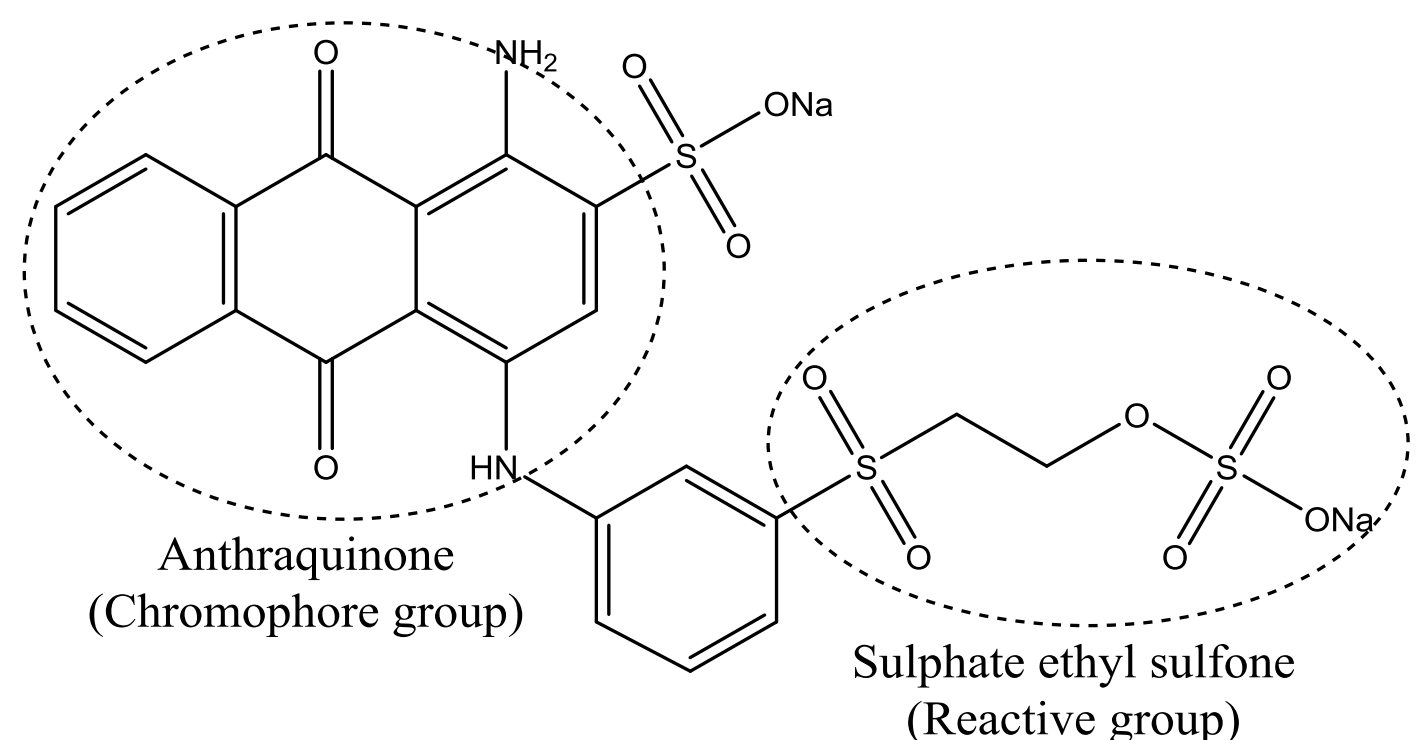

Scheme 1. Chemical structure of Remazol Blue RN.

\subsection{Preparation of sodium KSF (KSF-Na)}

Pristine montmorillonite-KSF was treated with a $0.1 \mathrm{~mol} \mathrm{dm}^{-3} \mathrm{NaCl}$ for $24 \mathrm{~h}$ at $323 \mathrm{~K}$ as described previously [38]. The cation exchange capacity of the KSF-Na was $60 \operatorname{cmol}(+) \mathrm{Kg}^{-1}[38]$.

\subsection{Preparation of KSF-montmorillonite-chitosan beads}

KSF-Na was suspended in $150 \mathrm{~cm}^{3}$ of deionized water and the suspension was mechanically stirred for $24 \mathrm{~h}$ without heating. The w/w percentages of Na-KSF were 1 , 5,15 or $25 \%$ regarding the chitosan amount in the composite beads. To the clay suspension, $3.0 \mathrm{~cm}^{3}$ of acetic acid and $3.0 \mathrm{~g}$ of $\mathrm{CS}$ were added and stirred for $24 \mathrm{~h}$ at room temperature. The gel was dropped slowly in the m/v 10\% TPP solution. The KSFCTS beads were matured for $24 \mathrm{~h}$ in the crosslinker solution, with distilled water up to neutral $\mathrm{pH}$ and dried at room temperature. 


\subsection{Dye removal}

The influence of the $\mathrm{pH}$ on dye removal was investigated at the 2-8 $\mathrm{pH}$ range. Samples of $50 \mathrm{mg}$ of the beads were then suspended in $20.0 \mathrm{~cm}^{3}$ dye solution at $500 \mathrm{mg}$ $\mathrm{L}^{-1}$ and were maintained under agitation at $298 \pm 1 \mathrm{~K}$. The system was centrifuged and the residual dye concentration $\left(\mathrm{C}_{\mathrm{e}}\right)$ was determined at $592 \mathrm{~nm}$ in a Shimadzu UV-Vis spectrometer, CBT-240 model. The amount of adsorbed dye was calculated by

\section{Equation 1,}

$$
q=\frac{\left(C_{i}-C_{e}\right) V}{m}
$$

where $C_{i}$ and $C_{e}$ are the initial and equilibrium dye concentrations $\left(\mathrm{mg} \mathrm{L}^{-1}\right), \mathrm{V}$ is the solution volume (L) and $\mathrm{m}$ is the mass of the solid (mg).

For the sorption kinetic study, the same procedure was followed for times until 660 minutes at the optimal $\mathrm{pH}$.

For the equilibrium isotherm, initial dye concentrations varied from 100 to 1600 $\mathrm{mg} \mathrm{L} \mathrm{L}^{-1}$, under optimum $\mathrm{pH}$ and established time.

To ensure reproducible measurement results, the adsorption experiments were carried out in triplicate.

\subsection{Characterizations}

CHN elemental analyzes were performed at a Perkin-Elmer analyzer, PE Model 2400. XRD patterns of the powdered samples were performed using a Shimadzu XD3A diffractometer. FTIR spectra were collected with a Bomem MB-series spectrophotometer using $\mathrm{KBr}$ pellets. Thermogravimetric analysis was performed by a Shimadzu TGA-50H thermobalance. Surface morphology of samples was determined SEM in a JEOL JSTM-300 microscope. TEM was performed on a Philips CM 200 microscope operating at $200 \mathrm{kV} .{ }^{13} \mathrm{C} \mathrm{CP}-\mathrm{MAS}$ NMR spectra were obtained on a Bruker 
Avance 500 spectrometer operating at $125 \mathrm{MHz}$. The point of zero charge $\left(\mathrm{pH}_{\mathrm{PZC}}\right)$ was determined after grinding the samples as previously described [47].

\section{Results and Discussion}

\subsection{Characterization of chitosan-KSF hybrids}

\subsubsection{Composition, structural, thermal and morphologic characterizations}

CHN results (Table 1) were used to estimate the content of clay mineral in the composites (Details see Table SM 1, ES 1, Equations 2 to 5) and $\mathrm{DD}_{\text {average once the }}$ crosslinking with TPP does not affect the quantity of acetylated and deacetylated units of the chitosan. In other words, the DD should not be affected in the various composites. The estimated values varied around $78 \pm 2$ in the composites. The pristine KSF-Na showed $\mathrm{C}<0.3 \%$ and $\mathrm{N}<0.05 \%$. The carbon and nitrogen contents decreased proportionally with the increasing of $\mathrm{KSF}-\mathrm{Na}$ in the composite. The experimental quantities of the clay mineral were in agreement with the proposal compositions $(1,5$, 15 and $25 \%$ ) suggesting the clay mineral was totally incorporated in the beads. The quantities of organic groups $\left(\mathrm{q}_{\mathrm{N}}\right)$ in the composites were estimated based on nitrogen content and the high obtained values for all composites were in agreement with the amount of chitosan in the beads. 
Table 1. CHN content for the pristine chitosan and their composites with KSF-Na, the quantity of organic groups on the solids $\left(\mathrm{q}_{\mathrm{N}}\right)$ and estimated degrees of deacetylation (DD) for chitosan.

\begin{tabular}{lcccrc}
\hline \multicolumn{1}{c}{ Sample } & $\mathrm{C}$ & $\mathrm{H}(\%)$ & $\mathrm{N}(\%)$ & $\mathrm{q}_{\mathrm{N}}\left(\mathrm{mmol} \mathrm{g}^{-1}\right)$ & $\mathrm{DD}(\%)$ \\
\hline CS & $38.29 \pm 0.05$ & $7.09 \pm 0.13$ & $6.84 \pm 0.02$ & 4.89 & $74 \pm 1$ \\
KSF-CTS-1\% & $38.08 \pm 0.05$ & $7.02 \pm 0.07$ & $6.88 \pm 0.02$ & 4.91 & $78 \pm 2$ \\
KSF-CTS-5\% & $36.09 \pm 0.07$ & $6.90 \pm 0.01$ & $6.54 \pm 0.00$ & 4.67 & $78 \pm 1$ \\
KSF-CTS-15\% & $33.09 \pm 0.02$ & $6.36 \pm 0.01$ & $5.95 \pm 0.04$ & 4.25 & $76 \pm 2$ \\
KSF-CTS-25\% & $29.30 \pm 0.26$ & $5.69 \pm 0.06$ & $5.36 \pm 0.02$ & 3.83 & $81 \pm 4$ \\
\hline
\end{tabular}

The IR spectrum of KSF-Na (Figure 1i-a), showed hydroxyl stretching bands located at $3634 \mathrm{~cm}^{-1}$ assigned to $\mathrm{M}-\mathrm{OH}$ stretching $(\mathrm{M}=\mathrm{Mg}, \mathrm{Al})$ of the octahedral sheets and at $3446 \mathrm{~cm}^{-1}$ and $1645 \mathrm{~cm}^{-1}$ attributed to the stretching and bending vibrations of the hydroxyl groups of interlayer water, respectively [48, 49]. The bands between 1120 and $470 \mathrm{~cm}^{-1}$ were associated to $\mathrm{Si}-\mathrm{O}-\mathrm{Si}$ stretching and $\mathrm{Si}-\mathrm{O}-\mathrm{Al}$ deformation, respectively $[49,50]$. The characteristic $\mathrm{Si}-\mathrm{O}$ asymmetric and symmetric stretchings appeared at 1100 and $1040 \mathrm{~cm}^{-1}$, respectively [51-53], and the Si-O-Si deformation was detected at $525 \mathrm{~cm}^{-1}$ [49]. The bands between $916\left(\mathrm{Al}_{2} \mathrm{OH}\right)$ and $840 \mathrm{~cm}^{-1}$ (AlMgOH) corresponded to the octahedral layer of the clay mineral and reflected the partial substitution of $\mathrm{Al}$ octahedral by $\operatorname{Mg}[49,52]$. The band at $631 \mathrm{~cm}^{-1}$ was associated to quartz [49, 53]. 
The infrared spectrum of chitosan (Figure 1i-b) showed characteristic bands at 2920 and $2850 \mathrm{~cm}^{-1}$ assigned to $\mathrm{C}-\mathrm{H}$ asymmetric and symmetric stretchings and a strong broad band around $3400 \mathrm{~cm}^{-1}$ assigned to the overlapping of $\mathrm{O}-\mathrm{H}$ and $\mathrm{N}-\mathrm{H}$ stretchings [54-56]. The band around $1655 \mathrm{~cm}^{-1}$ was associated with the $\mathrm{NH}$ stretching and the $\mathrm{C}=\mathrm{O}$ axial stretching from residual amide $[54,56]$. Other characteristic bands were observed at: $1558 \mathrm{~cm}^{-1}$, associated with $\mathrm{NH}_{3}{ }^{+}$deformation [20, 27, 57], 1420 and $1320 \mathrm{~cm}^{-1}$ which were assigned to the $\mathrm{C}-\mathrm{N}$ axial deformations from $-\mathrm{CH}_{2}$ and amide III bands, respectively $[55,56]$; and at $1380 \mathrm{~cm}^{-1}$ which was attributed to $\mathrm{CH}-$ deformation of methyl group in $\mathrm{N}$-acetyl $[55,56]$. Other bands were located at 1072 and $1029 \mathrm{~cm}^{-1}$, due to glucopyranosidic ring stretchings $[56,58] ; 1153 \mathrm{~cm}^{-1}$, associated with betaglycosidic bond between carbons 1 and 4 and $890 \mathrm{~cm}^{-1}$ also associated with polysaccharide structure $[10,11,34,59]$.

The characteristic bands of both KSF-Na and CS were observed in the spectra of beads (Figure 1i-c-f). However, the displacement of N-H deformation band at 1558 $\mathrm{cm}^{-1}$ for lower frequencies in the composites $\left(1541 \mathrm{~cm}^{-1}\right)$ suggested the interaction between the protonated amino groups of chitosan, TPP and the negative charge on the silicate layers $[23,33,60,61]$.

Although there are several procedures to determine $\mathrm{DD}_{\text {average }}$ for chitosan [6264], IR spectroscopy is widely used [56, 65]. Therefore, Equation 6 [66] was applied to determine DD for pure chitosan (CS):

$$
D D=97.67-\left[26.486\left(A_{1655} / A_{3400}\right)\right]
$$

Thus, the DD value was $78 \pm 1$ for CS, in agreement with the estimated value by CHN.

KSF-Na diffraction patterns (Figure 1ii-a) presented characteristic reflection at $2 \theta$ $=6.29^{\circ}$, which was associated to the basal spacing $\left(\mathrm{d}_{001}\right)$ of $1.40 \mathrm{~nm}$. Although the basal 
space has been reached a higher value than observed for montmorillonite around $1.2 \mathrm{~nm}$ [67-69], the same value was previously found $[47,70,71]$, the higher value can be related to the acid treatment of raw KSF and the sodium exchange. Other characteristic peaks of montmorillonite occurred at $2 \theta \cong 20^{\circ}\left(\mathrm{d}_{020}=0.45 \mathrm{~nm}\right)$ and $35^{\circ}\left(\mathrm{d}_{006}=0.26 \mathrm{~nm}\right)$. Impurities of muscovite and quartz were also detected.

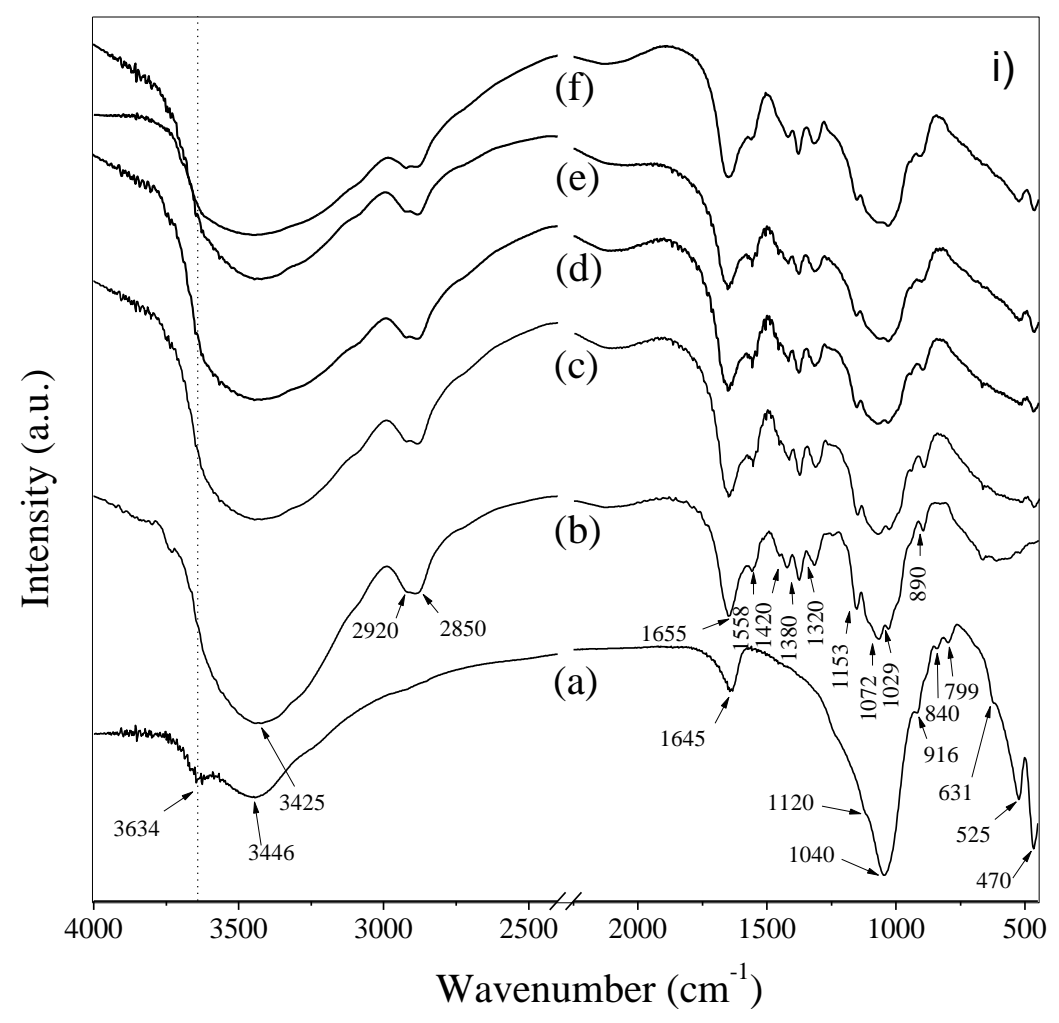




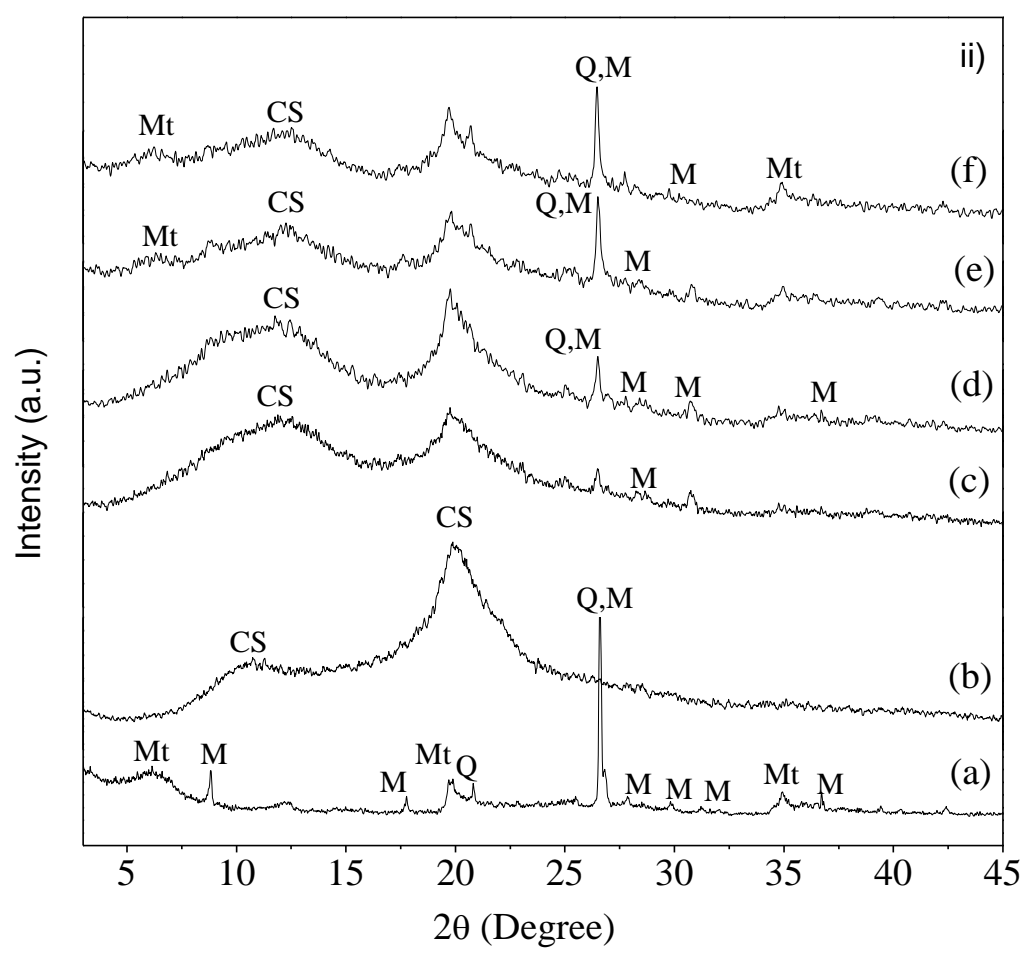

Figure 1. i) Infrared spectra and ii) for X-ray diffractograms for (a) KSF-Na, (b) CS, (c) KSF-CTS-1\%, (d) KSF-CTS-5\%, (e) CTS-KSF-15\% and (f) KSF-CTS-25\%. Mt. montmorillonite; M, muscovite; Q, quartz; CS, chitosan.

The X-ray diffraction patterns of CS inferred about the efficiency of deacetylation of chitin and other preliminary steps that consists in the removal of minerals, primarily $\mathrm{CaCO}_{3}$. The characteristic diffraction peaks of CS appeared (Figure 1ii-b) at $2 \theta \cong 10^{\circ}$ $\left(\mathrm{d}_{020}=0.82 \mathrm{~nm}\right)$ and $2 \theta \cong 20^{\circ}\left(\mathrm{d}_{110}=0.45 \mathrm{~nm}\right)$ were assigned to the crystalline regions formed by hydrogen bonds between the amino and hydroxyl groups of the CS chains $[17,72]$. The absence of reflection at $2 \theta \cong 30^{\circ}$ suggested $\mathrm{CaCO}_{3}$ removal in the demineralization of the precursor chitin [73].

The XRD patterns of the composites showed characteristic peaks of both KSF-Na and CS (Figure 1ii-c-f). For all prepared beads, the patterns presented broad peaks with low degree of crystallinity as observed in other studies $[34,40]$. The reflection at $2 \theta=$ 
$6.29^{\circ}\left(\mathrm{d}_{001}\right)$ of montmorillonite almost disappeared, indicating highly disordered intercalated or probably exfoliated montmorillonite [20, 74]. Also only broad reflections of CS were observed with maintenance of the peak at $2 \theta \cong 20^{\circ}$ in all samples.

The reaction between KSF-CS gels in the TPP solution involves the electrostatic interactions between protonated amino groups of the CS and the negative TPP, which resulted in the gelatinous beads. Thus, SEM studies only provide the information concerning the general morphology of the chitosan-clay composite. The surface chitosan-clay beads remained non-porous and became more irregular or roughened with the increasing of the KSF content in the composites (Figure 2). 


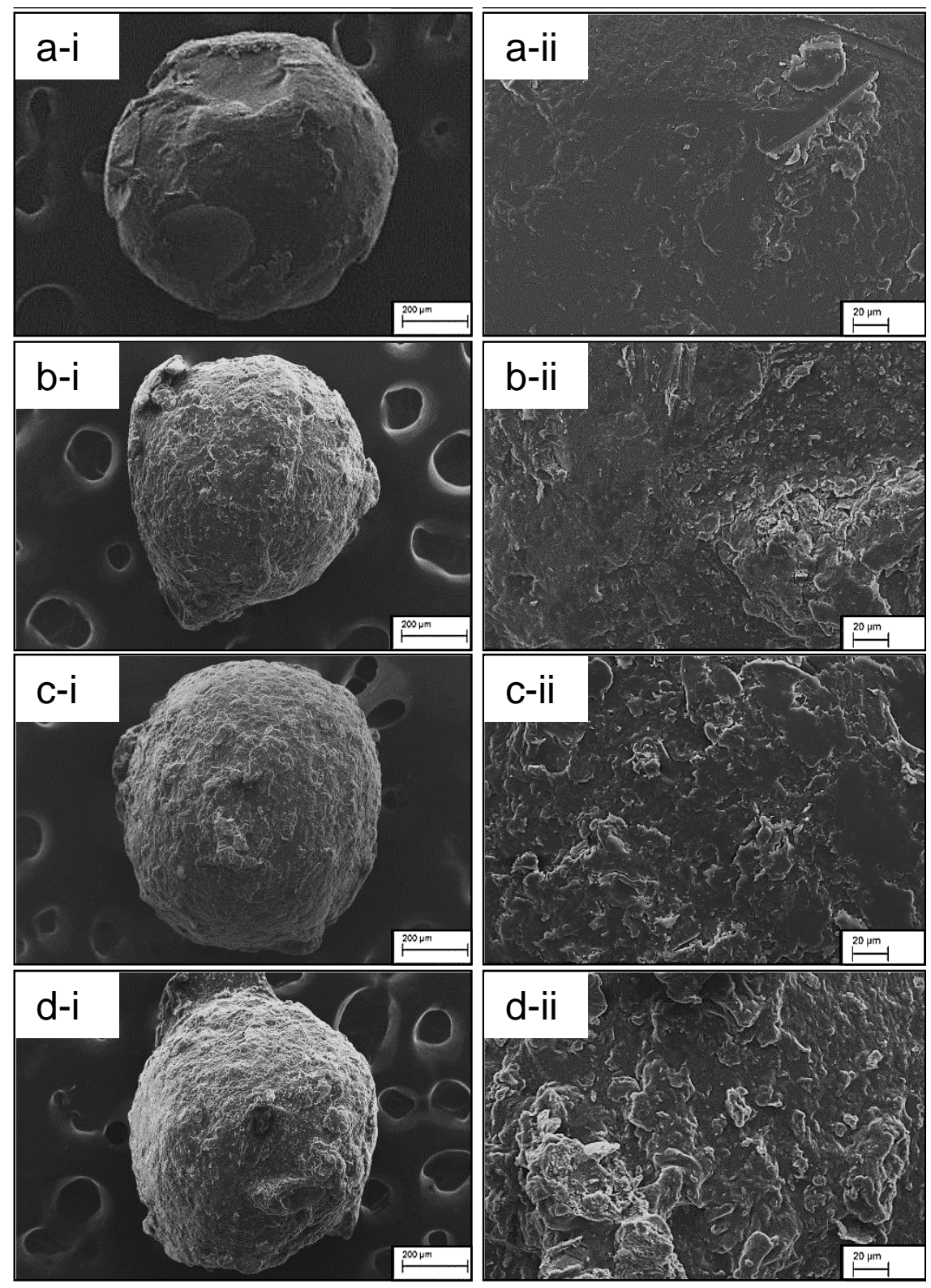

Figure 2. SEM images for (a) KSF-CTS-1\%, (b) KSF-CTS-5\%, (c) KSF-CTS-15\% and (d) KSF CTS-25\%, at magnifications of 200x (i) and 1000x (ii). 
In order to analyze the structural effects of adding KSF-Na in the prepared nanocomposites, TEM were performed. The TEM images (Figure 3) showed the typical lamellar structure of the KSF-Na (Figure 3-a), however exfoliated and separate phases coexisted in the resultant composites (Figure 3-b-e). These data corroborate the changes seen in the XRD patterns of the composites. Other studies related to chitosanclay composites in powder form concluded the simultaneous formation of exfoliated and intercalated forms $[20,75,76]$.
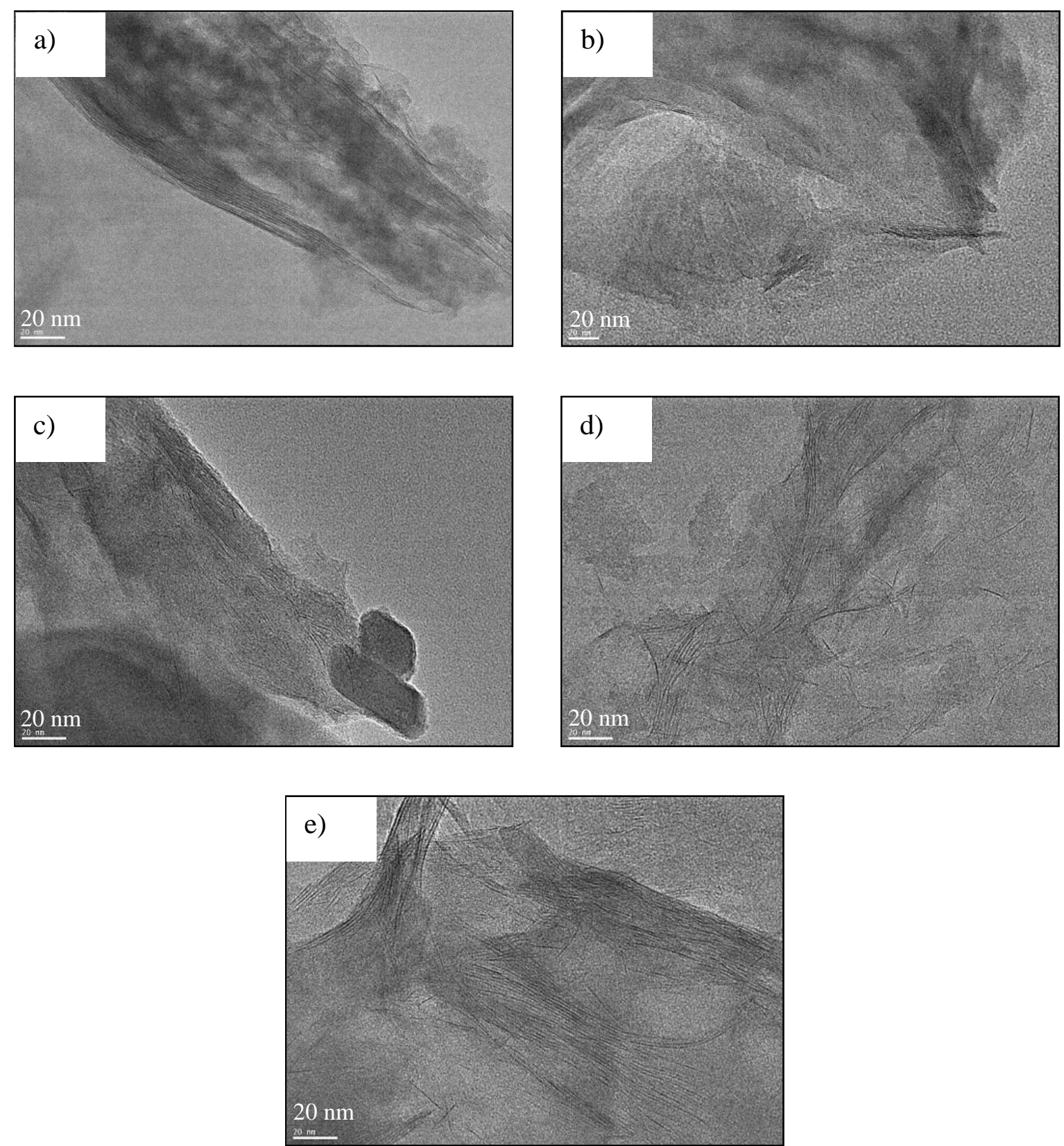
Figure 3. TEM images for (a) KSF-Na, (b) KSF-CTS-1\%, (c) KSF-CTS-5\%, (d) KSFCTS-15\% and (e) KSF-CTS- $25 \%$.

The ${ }^{13} \mathrm{C}$ CP-MAS spectrum of pristine chitosan (Figure 4) presents characteristic signals at 105, 58, 83 and $61 \mathrm{ppm}$, assigned to the C1, C2, C4, C6 carbon atoms of the ring, respectively $[49,64]$. Additionally, the signal at $76 \mathrm{ppm}$ was related to C3 and C5 carbon atoms of the chitosan. The signals at 24 and $175 \mathrm{ppm}$ were associated with the remaining methyl and carbonyl groups due the incomplete deacetylation of the chitin $[62,77]$. The same signals were observed in the composites suggesting that the chemical structure of the chitosan was maintained $[23,78,79]$.

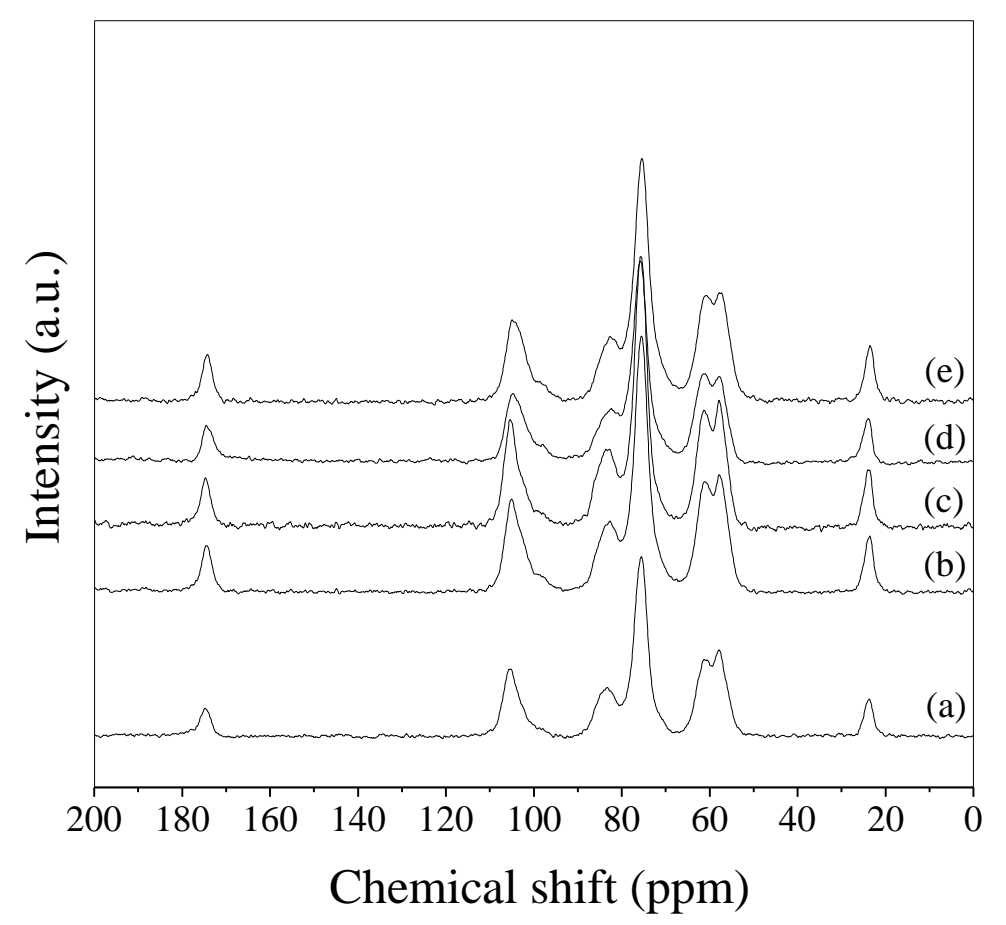

Figure 4. ${ }^{13} \mathrm{C}$ NMR spectra for (a) CS, (b) KSF-CTS-1\%, (c) KSF-CTS-5\%, (d) KSFCTS-15\% and (e) KSF-CTS-25\%. 


\subsubsection{Point of zero charge $\left(\mathrm{pH}_{P C Z}\right)$}

KSF-Na surface is negatively charged in aqueous solution due to isomorphous substitutions of $\mathrm{Al}^{3+}$ for $\mathrm{Si}^{4+}$ in the tetrahedral layer and $\mathrm{Mg}^{2+}$ for $\mathrm{Al}^{3+}$ in the octahedral layer on montmorillonite [11, 80], (See Figure SM 1-a).

The isoelectric point of the CS was close to neutral (pH 6.5) (Figure SM 1-b). In acidic solution, the chitosan amino groups are protonated by $\mathrm{H}^{+}$by the solution, which increases the $\mathrm{pH}$ [81]. The alkaline solution, the amino groups of chitosan are deprotonated, resulting in an excess of negative surface charge [82, 83].

In the KSF-Na/CTS composites, the $\mathrm{pH}_{\mathrm{PCZ}}$ was more negative at lower $\mathrm{pH}$ as the KSF was added to beads, which indicated better chemical stability at acid medium. In fact, $\mathrm{CS}$ is soluble at $\mathrm{pH}$ lower than 4 forming gel, partially soluble at $\mathrm{pH} 4-6$ and stable at $\mathrm{pH}$ higher than 6. CTS and KSF-CTS-1\% were partially soluble at $\mathrm{pH}$ lower than 4 and stable at $\mathrm{pH}$ equal or higher than 4 . The composites with 5-25\% of KSF-Na became partially soluble at $\mathrm{pH}<3$ and stable at $\mathrm{pH} \geq 3$. These results indicated that the presence of the KSF-Na in the beads promoted a higher resistance to the dissolution of chitosan in acidic conditions.

\subsection{Anionic dye removal study}

\subsubsection{Effect of pH solution}

It is well-established that $\mathrm{pH}$ influences the adsorption of a given specie due to the variation of charges between the adsorbed species and the surface of the adsorbent [18, $59,82,84]$. As UV-Vis spectrum is influenced by the solvent $[85,86]$, the behavior of dye at $\mathrm{pH} 3$ to 8 was monitored (See Figure SM 2). Characteristics bands were observed in the UV-Vis spectra with partial overlap of two well-resolved bands between 450-700 nm, assigned to the $\pi \rightarrow \pi^{*}$ and $\mathrm{n} \rightarrow \pi^{*}$ transitions of the dye [85]. 
In order to check the optimum $\mathrm{pH}$ for adsorption, the process was monitored at the $\mathrm{pH}$ range of 2-8 (Figure 5). The $\mathrm{RB}$ sorption onto the beads was $\mathrm{pH}$-dependent, which the maximum uptake of $\mathrm{RB}$ was achieved at $\mathrm{pH}$ 3. At lower $\mathrm{pH}$, the primary amino groups of the CS and KSF-CTS composites beads become protonated $\left(-\mathrm{NH}_{3}{ }^{+}\right)$ and the surface of the beads became positively charged [86-88]. Simultaneously, sulfonate groups of the dye (Dye- $\mathrm{SO}_{3} \mathrm{Na}$ ) were dissociated in an aqueous solution (Dye- $-\mathrm{SO}_{3}{ }^{-}$) [88]. Therefore, electrostatic interactions were favorable between the positively charged surface and the anionic $\mathrm{RB}$ dye at $\mathrm{pH}$ 3. This implies that strong electrostatic attraction is the dominant role for uptake of $\mathrm{RB}$ dye onto the given adsorbents, which can be favor the possible reuse of the adsorbents after RB desorption in alkaline medium.

Although the CS presented sorption capacity equivalent to the prepared composites, they proved to be inadequate to the sorption process when the $\mathrm{pH}$ is lower than 3.0 due to their partial dissolution, which results in loss of the adsorbent during the process. Moreover, no significant interactions occurred between KSF-Na and RB in the pH studied.

Figure 5. pH effect over Remazol blue adsorption for (a) CS, (b) KSF-CTS-1\%, (c) KSF-CTS- 5\%, (d) CTS-KSF-15\% and (e) KSF-CTS-25\% samples at $500 \mathrm{mg} \mathrm{L}^{-1}, 24 \mathrm{~h}$ and $298 \mathrm{~K}$. In order to provide a better visualization, the $\mathrm{Y}$ axis data were divided in $1.0,1.1,1.4,1.8$ and 2.4 times for the samples a-e, respectively. 


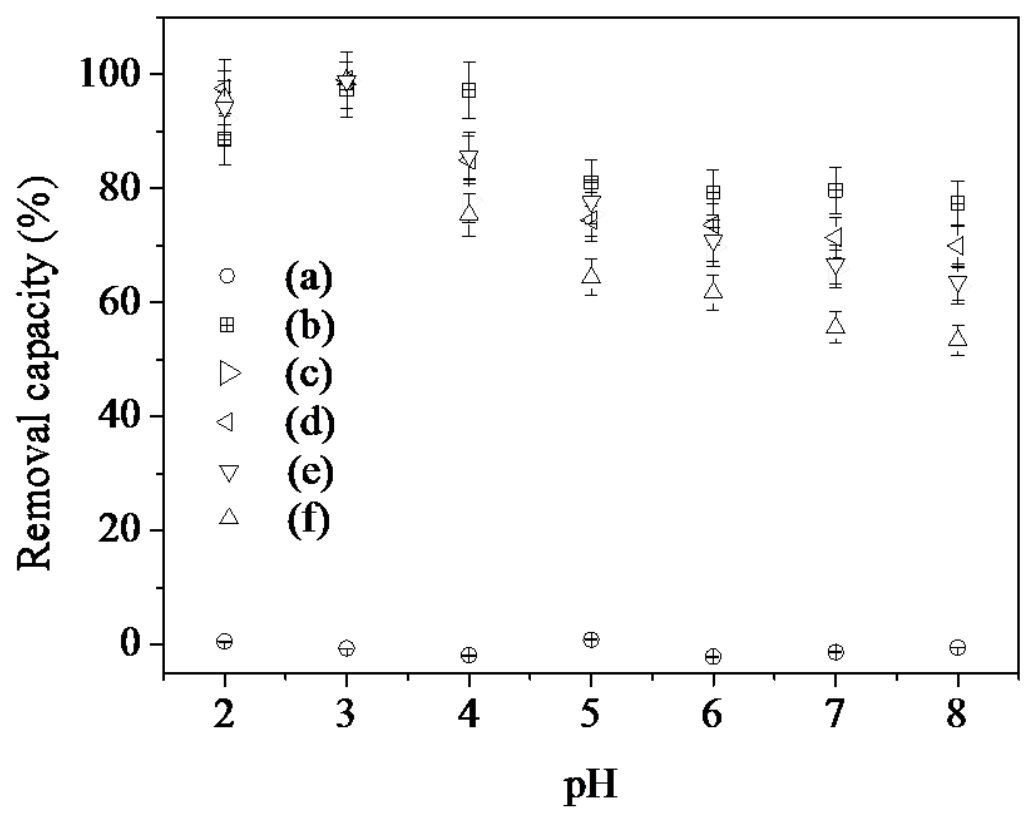

Figure 5. pH effect over Remazol blue adsorption for (a) CS, (b) KSF-CTS-1\%, (c) KSF-CTS- 5\%, (d) CTS-KSF-15\% and (e) KSF-CTS-25\% samples at $500 \mathrm{mg} \mathrm{L}^{-1}, 24 \mathrm{~h}$ and 298 K. In order to provide a better visualization, the $\mathrm{Y}$ axis data were divided in $1.0,1.1,1.4,1.8$ and 2.4 times for the samples a-e, respectively.

\subsubsection{Effects of time on adsorption}

The time isotherms are required for the preliminary study of the adsorptive process because they provide information about the kinetic for complete interaction to the surface of the adsorbent. Chitosan and composites were used with a $500 \mathrm{mg} \mathrm{L}^{-1}$ dye solution, under pre-determined $\mathrm{pH}$ previously obtained (Figure 6). Although time isotherms for $\mathrm{RB}$ dye reached equilibrium at $480 \mathrm{~min}$ for the prepared composites beads, it can be seen that at least $77 \%\left(160 \mathrm{mg} \mathrm{g}^{-1}\right)$ of dye have been removed for all compositions at $240 \mathrm{~min}$. Similar results were found for other based-chitosan materials [11, 40, 89-91], i.e. Mirmohseni, Seyed Dorraji, Figoli and Tasselli [91] reached a RB 
dye removal efficiency around $80 \%$ at 240 min and $\mathrm{pH} 3.5$ into chitosan hollow fibers biosorbents.

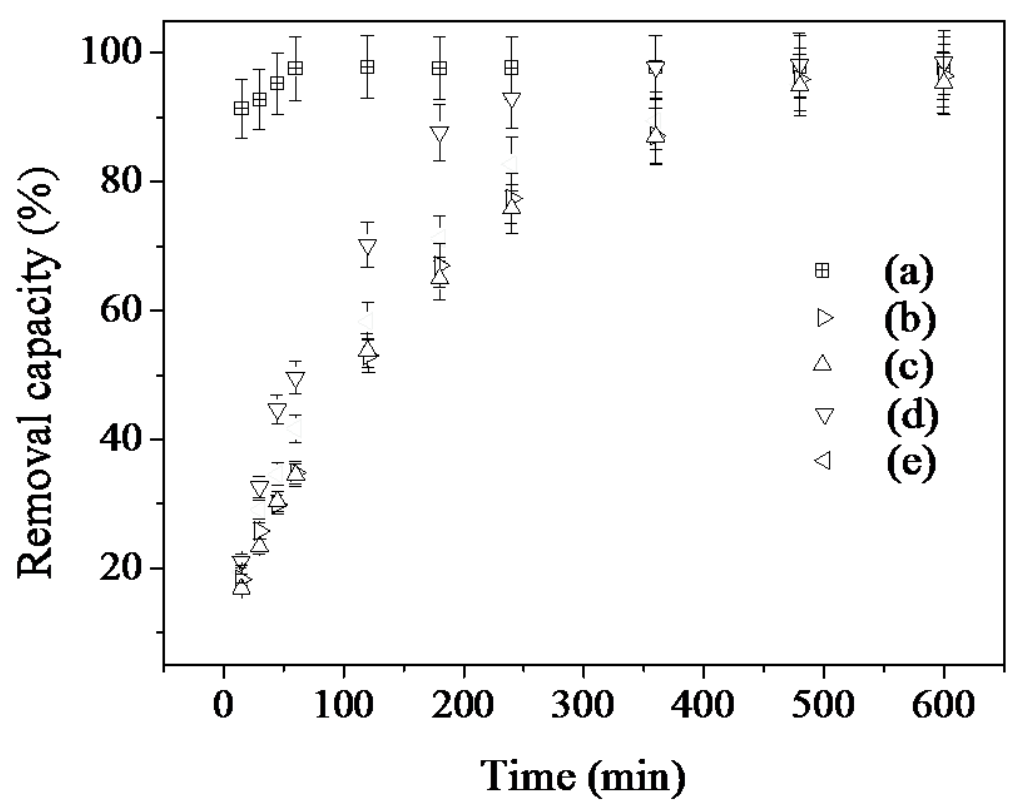

Figure 6. Time effect over Remazol blue removal for (a) CS, (b) KSF-CTS-1\%, (c) KSF-CTS-5\%, (d) KSF -CTS-15\% and (e) CTS-KSF-25\% at $500 \mathrm{mg} \mathrm{L}^{-1}$, pH 3 and 298 $\mathrm{K}$. In order to provide a better visualization, the $\mathrm{Y}$ axis data were divided in 1.0, 1.1, 1.4, 1.8 and 2.4 times for the samples a-e, respectively.

The experimental data were fitted to pseudo-first order [92] and pseudo-second order models [93], as described the Equations 7 and 8,

$$
\log \left(q_{e}-q_{t}\right)=\log q_{e}-\frac{k_{1}}{2.303} t
$$

Where $q_{e}$ and $q_{t}$ are the amount of adsorbed dyes in equilibrium and at a time $t$ and $k_{l}$ is the constant pseudo-first-order rate.

$$
\frac{t}{q_{t}}=\frac{1}{k_{2} q_{e}^{2}}+\frac{t}{q_{e}}
$$

Where $k_{2}$ is the rate constant of pseudo-first order rate. 
The results indicated that adsorption fitted well with the pseudo-second kinetic model with a high value of coefficient of determination $\left(\mathrm{R}^{2}\right)$ and a close agreement between experimental and estimated qe values (Figures SM 3, SM 4 and Table 2). It is known that the rate-limiting step for this model is the sorption mechanism involving chemisorption. Although passive diffusion agree with the time found to reach equilibrium in the isotherms, some other reaction mechanism may also been involved in the removal of the present dye. In addition, the rate constant $\left(\mathrm{k}_{2}\right)$ was affected by the KSF content in composites, which faster adsorption kinetics were observed for the composites with higher KSF quantity. Other chitosan-clay composites showed the same behavior for dyes removal [27, 94-96].

Table 2 - Kinetic parameters for the Remazol blue adsorption on chitosan samples and its composites with KSF-Na, according to the models of pseudo-first order and pseudosecond order at $500 \mathrm{mg} \mathrm{L}^{-1}, \mathrm{pH} 3$ and $298 \pm 1 \mathrm{~K}$.

\section{Sample}

CS $\quad$ KSF-CTS-1\% $\quad$ KSF-CTS-5\% $\quad$ KSF-CTS-15\% $\quad$ KSF-CTS-25\%

$\mathrm{q}_{\mathrm{e}(\exp )}$

$201.61 \pm 0.482 \quad 205.32 \pm 0.817 \quad 210 \pm 0.436 \quad 212.79 \pm 0.380 \quad 208.98 \pm 0.430$

\section{Pseudo-first order model}

qe (teor.)

$\mathrm{k}_{1}$

$\mathrm{R}^{2}$

Pseudo-second order model
18.48

$7.9210^{-3}$

0.5481
172.79

$1.4110^{-3}$

0.9658
157.36

$3.9810^{-3}$

0.3624
217.89

$7.4510^{-5}$

0.9968
164.87

$6.2610^{-3}$

0.9794 $\mathrm{q}_{\mathrm{e}}$ (teor.)

$\mathrm{k}_{2}$

$\mathrm{R}^{2}$
195.31

$1.2910^{-2}$

0.9979
201.04

$2.5710^{-5}$

0.9782
218.34

$4.1810^{-5}$

0.9946
$1.1710^{-2}$

0.8612
214.67

$5.6110^{-5}$

0.9962 


\subsubsection{Effect of the dye concentration}

The equilibrium isotherms for RB are presented in Figure 7. Although KSF does not present any affinity to $\mathrm{RB}$ due to its negatively surface, the $\mathrm{q}_{\mathrm{e}}$ values were varied between 289 to $310 \mathrm{mg} \mathrm{g}^{-1}$ and suggest that the composition of the composites applied did not highly affect the adsorption capacity of the composites. According to literature dye adsorption on based chitosan/montmorillonite materials was influenced by the ratios of chitosan to clay mineral $[23,30,34,88]$. In the present study, based on CHN results, the lower quantity of chitosan in the beads was $3.83 \mathrm{mmol} \mathrm{g}^{-1}$ in the KSF-CTS$25 \%$, which value is seven times higher than the maximum dye removal in the composite $\left(310 \mathrm{mg} \mathrm{g}^{-1}\right.$ or $\left.0.5 \mathrm{mmol} \mathrm{g}^{-1}\right)$.

Furthermore, the increase of the KSF amount in the prepared composites has contributed to obtain a low-cost adsorbent for anionic dye with a higher resistance in acidic solutions. Other point is the facility of separation of the beads after adsorption.

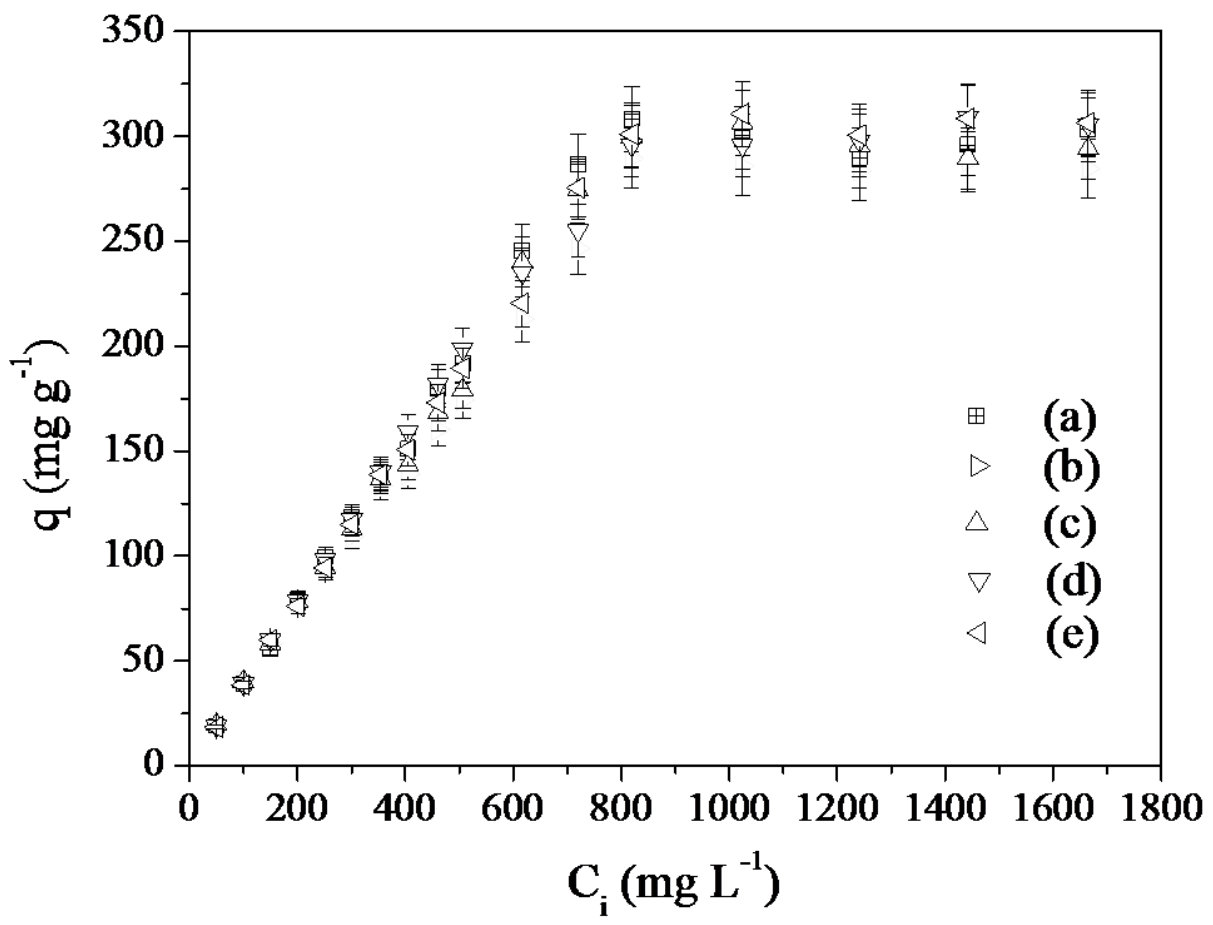


Figure 7. Effect of the dye initial concentration on Remazol blue sorption for (a) CS, (b) KSF-CTS-1\%, (c) KSF-CTS-5\% (d) KSF-CTS-15\% and (e) CTS-KSF-25\% at 100$1600 \mathrm{mg} \mathrm{L}^{-1}, \mathrm{pH} 3$ and $298 \mathrm{~K}$. In order to provide a better visualization, the $\mathrm{Y}$ axis data were divided in 1.0, 1.1, 1.4, 1.8 and 2.4 times for the samples a-e, respectively.

The data were adjusted to Langmuir [97] and Freundlich models (Details see Figure SM 5) [98]. The Langmuir (Equation 9) model was applied for describing the adsorption data:

$$
\frac{C_{e}}{q_{e}}=\frac{C_{e}}{q_{\max }}+\frac{1}{b q_{\max }}
$$

where $C_{e}$ is the concentration of dye in equilibrium; $q_{e}$ is the amount of adsorbed dye at the solid/liquid interface and $q_{\max }$ is the monolayer adsorption capacity of the adsorbent, both in terms of quantity of material by mass of function; $b$ is the Langmuir adsorption constant associated with adsorption energy.

The Freundlich model [98] is based on the heterogeneity or non-uniformity of sites on solid and the multilayer adsorption and is expressed as Equation 10,

$$
\ln q_{e}=\ln k_{F}+\frac{1}{n} \ln C_{e}
$$

where $k_{F}$ and $1 / n$ are empirical parameters of the Freundlich model. $k_{F}$ is the adsorption constant, related to the binding energy, and $1 / n$ is connected to the heterogeneity of the solid surface. The parameter $n$ is a measure of the deviation from linearity of the adsorption and indicates the degree of non-linearity between the solution concentration and adsorption.

The resulted parameters are summarized in Table 3. Langmuir model showed higher $\mathrm{R}^{2}$ than Freundlich model for the prepared composites and $\mathrm{q}_{\max }$ closed to $\mathrm{q}_{\mathrm{e}}$ 
values and exhibited an adsorption capacity around $310 \mathrm{mg} \mathrm{g}^{-1}$ for RB removal, suggesting the monolayer of the anionic dye on composites and that chemisorptions is the principal mechanism of interaction between the anionic dye and $\left(-\mathrm{NH}_{3}{ }^{+}\right)$protonated surface of the beads.

Table 3 - Adsorption isotherms parameters for the Remazol blue on chitosan samples and their composites with KSF-Na, according to the models of Langmuir and Freundlich at $100-1600 \mathrm{mg} \mathrm{L}^{-1}, \mathrm{pH} 3$ and $298 \pm 1 \mathrm{~K}$.

Sample

Model

CS $\quad$ KSF-CTS-1\% $\quad$ KSF-CTS-5\% $\quad$ KSF-CTS-15\% $\quad$ KSF-CTS-25\%

\section{Langmuir}

$\begin{array}{lccccc}\mathrm{q}_{\mathrm{e}}\left(\mathrm{mg} \mathrm{g}^{-1}\right) & 308.34 \pm 0.487 & 289.69 \pm 0.890 & 306.18 \pm 0.683 & 309.18 \pm 0.493 & 310.73 \pm 0.556 \\ \mathrm{q}_{\max }\left(\mathrm{mg} \mathrm{g}^{-1}\right) & 300.30 & 290.70 & 334.78 & 308.64 & 308.64 \\ \mathrm{~b}\left(\mathrm{dm} \mathrm{g}^{-1}\right) & 0.2502 & 0.0606 & 0.1544 & 0.1192 & 0.1528 \\ \mathrm{R}^{2} & 0.9994 & 0.9979 & 0.9981 & 0.9979 & 0.9995\end{array}$

\section{Freündlich}

\begin{tabular}{llllll}
$\mathrm{K}_{\mathrm{f}}$ & 7.5254 & 6.5914 & 7.7302 & 6.7924 & 6.3934 \\
$\mathrm{n}$ & 6.8451 & 4.9848 & 7.7302 & 4.3630 & 3.8319 \\
$\mathrm{R}^{2}$ & 0.4827 & 0.9522 & 0.7237 & 0.4399 & 0.6230 \\
\hline
\end{tabular}


Adsorption capacities of RB dye into clay minerals (39.0 $\left.\mathrm{mg} \mathrm{g}^{-1}\right)$ [47], carbon nanotubes functionalized (211.0 $\left.\mathrm{mg} \mathrm{g}^{-1}\right)$ [99], chitosan-oil palm composite $\left(423.5 \mathrm{mg} \mathrm{g}^{-}\right.$ $\left.{ }^{1}\right)$ [100] and chitosan hollow fibers composites $\left(454.5 \mathrm{mg} \mathrm{g}^{-1}\right)$ [91] are reported in the literature (Table 4) and demonstrated that all prepared composites in the present work had a good efficiency to RB uptake from wastewater.

Table 4. Dye removal capacities of the chitosan-montmorillonite composites reported in this paper with similar adsorbents.

\begin{tabular}{|c|c|c|c|}
\hline Adsorbent & Dye & $\begin{array}{l}\text { Concentration of } \\
\text { dye } \quad\left(\mathrm{mg} \mathrm{L}^{-1}\right)\end{array}$ & $\begin{array}{c}\text { Adsorption } \\
\text { capacity (mg } \\
\left.\mathrm{g}^{-1}\right)\end{array}$ \\
\hline Chitosan & Remazol Blue RN & 1700 & $308^{*}$ \\
\hline Chitosan-modified palygorskite & Reactive Red 120 & 140 & $71^{94}$ \\
\hline $\begin{array}{l}\text { Chitosan-Organically modified } \\
\text { Nanoclay (Cloisite30B) }\end{array}$ & Reactive dyes RR-141 & 1000 & $443^{95}$ \\
\hline $\begin{array}{l}\text { Chitosan-Organically modified } \\
\text { Nanoclay (Cloisite30B) }\end{array}$ & Reactive dyes RB-21 & 1000 & $490^{95}$ \\
\hline $\begin{array}{l}\text { Chitosan/Bentonite cross-linked } \\
\text { with glutaraldehyde }\end{array}$ & Amido Black 10B & 550 & $324^{96}$ \\
\hline Chitosan/MMT membrane & Bezactiv Orange & 80 & $279^{23}$ \\
\hline $\begin{array}{l}\text { Chitosan/montmorillonite-1\% } \\
\text { cross-linked with TPP }\end{array}$ & Remazol Blue RN & 1700 & $290 *$ \\
\hline $\begin{array}{l}\text { Chitosan/montmorillonite-5\% } \\
\text { cross-linked with TPP }\end{array}$ & Remazol Blue RN & 1700 & $306^{*}$ \\
\hline $\begin{array}{l}\text { Chitosan/montmorillonite- } 15 \% \\
\text { cross-linked with TPP }\end{array}$ & Remazol Blue RN & 1700 & $309^{*}$ \\
\hline $\begin{array}{l}\text { Chitosan/montmorillonite- } 25 \% \\
\text { cross-linked with TPP }\end{array}$ & Remazol Blue RN & 1700 & $310^{*}$ \\
\hline
\end{tabular}




\subsection{Characterization of chitosan-KSF-anionic dye hybrids}

The post-adsorption samples presented some modifications in FTIR spectra (Figure SM 6-i). The strong and broader $\mathrm{O}-\mathrm{H}$ and $\mathrm{N}-\mathrm{H}$ groups overlapped stretching bands, originally at $3425 \mathrm{~cm}^{-1}$ in pristine composites, became sharper and shifted to $3437 \mathrm{~cm}^{-1}$ due to the presence of these groups from the RB sorption. The characteristic bands for the dye $\left(1624,1591,1529\right.$ and $\left.1408 \mathrm{~cm}^{-1}\right)$ [101] can overlapped with the composites structural bands. The band corresponding to vs $\left(\mathrm{Dye}-\mathrm{SO}_{3}\right)$ appears at 1192 $\mathrm{cm}^{-1}$. Moreover, the band at $1558 \mathrm{~cm}^{-1}$ (in CS and KSF-CTS) assigned to $-\mathrm{NH}_{3}{ }^{+}$shifted to $1578 \mathrm{~cm}^{-1}$ for KSF-CTS-RB composites indicating a possible interaction between the $-\mathrm{NH}_{3}{ }^{+}$groups and the basic sites of the dye.

The XRD patterns of the samples after RB adsorption (Figure SM 6-ii) showed similar reflections than those observed for montmorillonite and chitosan, suggesting the dye accommodation on surface of the beads.

The UV-Vis spectrum for KSF-Na showed an absorption band centered on 260 $\mathrm{nm}[102,103]$ and for chitosan two bands, a broad one at $300 \mathrm{~nm}$ and a sharp one at $400 \mathrm{~nm}$ (Figure SM 7) [104, 105]. The spectra of the chitosan-KSF/dye hybrids presented new broad band at around $600 \mathrm{~nm}$ associated probably with the bathochromic effect of the original absorption of the free dye at $543 \mathrm{~nm}$.

\section{Conclusions}

Beads chitosan/-montmorillonite-KSF at 1, 5, 15 and 25\% w/w proportions were prepared using sodium tripolyphosphate as crosslinker. XRD, FTIR and SEM results highlighted the interactions between the biopolymer and the clay mineral leading to a hybrid composite with better adsorption properties for the anionic dye. TEM showed 
co-existence of separated phases and exfoliated structures. Measurements of the zero charge potential $\left(\mathrm{pH}_{\mathrm{ZCP}}\right)$ suggested that isoelectric point shifted to lower $\mathrm{pH}$ with the increasing of montmorillonite content, which extends the application at more acidic medium.

The optimal conditions for the removal of Remazol Blue-RN from aqueous solution were $\mathrm{pH} 3$ during $480 \mathrm{~min}$. The processes were followed pseudo-second order kinetics, with the rate constant dependent on montmorillonite content in the composites. The equilibrium isotherms indicated that the Remazol blue sorption capacity was substantially independent of clay mineral content in the beads.

Thus, the prepared composites showed better adsorption properties than pure montmorillonite with maximum dye removal of $310 \mathrm{mg} \mathrm{g}^{-1}$ for the composite prepared with $25 \%$ of montmorillonite.

This study demonstrated that chitosan/KSF beads can be applied as versatile bioadsorbent for anionic dyes removal from solution in a wide range of $\mathrm{pH}$ and especially in acidic medium where the chitosan is soluble.

\section{Acknowledgments}

KSS was supported by a pos-doc grant from CNPq. CNPq is acknowledged for research fellowships to MGF and IMGS. CAPES/COFECUB (835/2015) for financial support.

\section{References}

[1] C. Wang, A. Yediler, D. Lienert, Z. Wang, A. Kettrup, Toxicity evaluation of reactive dyestuffs, auxiliaries and selected effluents in textile finishing industry to luminescent bacteria Vibrio fischeri, Chemosphere, 46 (2002) 339-344.

[2] D.T. Sponza, Toxicity studies in a chemical dye production industry in Turkey, Journal of Hazardous Materials, 138 (2006) 438-447. 
[3] H. Langhals, Color Chemistry. Synthesis, Properties and Applications of Organic Dyes and Pigments. 3rd revised edition. By Heinrich Zollinger, Angewandte Chemie International Edition, 43 (2004) 5291-5292.

[4] M. Khajeh, S. Laurent, K. Dastafkan, Nanoadsorbents: Classification, Preparation, and Applications (with Emphasis on Aqueous Media), Chemical Reviews, 113 (2013) 7728-7768.

[5] J. Rouquerol, P. Llewellyn, K.S.W. Sing, Adsorption by clays, pillared clays, zeolites and aluminophosphates, in: Elsevier (Ed.) Adsorption by Powders and Porous Solids: Principles, Methodology and Applications, Oxford, 2014, pp. 467-527.

[6] R. Zhu, Q. Zhou, J. Zhu, Y. Xi, H. He, Organo-clays as sorbents of hydrophobic organic contaminants: Sorptive characteristics and approaches to enhancing sorption capacity, Clays and Clay Minerals, 63 (2015) 199-221.

[7] G.D. Yuan, Theng, B.K.G., Churchman, G.J., Gates, W.P., Clays and clay minerals for pollution control, in: Elsevier (Ed.) Handbook of Clay Science, Part A, Amsterdam, 2013, pp. 587-644.

[8] R. Zhu, Q. Chen, Q. Zhou, Y. Xi, J. Zhu, H. He, Adsorbents based on montmorillonite for contaminant removal from water: A review, Applied Clay Science, 123 (2016) 239-258.

[9] I. Ali, New Generation Adsorbents for Water Treatment, Chemical Reviews, 112 (2012) 5073-5091.

[10] O.A.C. Monteiro Jr, C. Airoldi, The influence of chitosans with defined degrees of acetylation on the thermodynamic data for copper coordination, Journal of Colloid and Interface Science, 282 (2005) 32-37.

[11] W.S. Wan Ngah, L.C. Teong, M.A.K.M. Hanafiah, Adsorption of dyes and heavy metal ions by chitosan composites: A review, Carbohydrate Polymers, 83 (2011) 14461456.

[12] S.-h. Hsu, M.-C. Wang, J.-J. Lin, Biocompatibility and antimicrobial evaluation of montmorillonite/chitosan nanocomposites, Applied Clay Science, 56 (2012) 53-62.

[13] M.N. Kumar, R.A. Muzzarelli, C. Muzzarelli, H. Sashiwa, A.J. Domb, Chitosan chemistry and pharmaceutical perspectives, Chem Rev, 104 (2004) 6017-6084.

[14] F.-C. Wu, R.-L. Tseng, R.-S. Juang, A review and experimental verification of using chitosan and its derivatives as adsorbents for selected heavy metals, Journal of Environmental Management, 91 (2010) 798-806.

[15] Z. Bekçi, C. Özveri, Y. Seki, K. Yurdakoç, Sorption of malachite green on chitosan bead, Journal of Hazardous Materials, 154 (2008) 254-261.

[16] F.A.R. Pereira, K.S. Sousa, G.R.S. Cavalcanti, M.G. Fonseca, A.G. de Souza,

A.P.M. Alves, Chitosan-montmorillonite biocomposite as an adsorbent for copper (II) cations from aqueous solutions, International Journal of Biological Macromolecules, 61 (2013) 471-478.

[17] A.F. Martins, D.M. de Oliveira, A.G.B. Pereira, A.F. Rubira, E.C. Muniz, Chitosan/TPP microparticles obtained by microemulsion method applied in controlled release of heparin, International Journal of Biological Macromolecules, 51 (2012) 11271133.

[18] W.S.W. Ngah, S. Fatinathan, Adsorption characterization of $\mathrm{Pb}$ (II) and $\mathrm{Cu}(\mathrm{II})$ ions onto chitosan-tripolyphosphate beads: Kinetic, equilibrium and thermodynamic studies, Journal of Environmental Management, 91 (2010) 958-969.

[19] T. Pongjanyakul, A. Priprem, S. Puttipipatkhachorn, Investigation of novel alginate-magnesium aluminum silicate microcomposite films for modified-release tablets, Journal of Controlled Release, 107 (2005) 343-356. 
[20] S.F. Wang, L. Shen, Y.J. Tong, L. Chen, I.Y. Phang, P.Q. Lim, T.X. Liu, Biopolymer chitosan/montmorillonite nanocomposites: Preparation and characterization, Polymer Degradation and Stability, 90 (2005) 123-131. [21] T.-M. Wu, C.-Y. Wu, Biodegradable poly(lactic acid)/chitosan-modified montmorillonite nanocomposites: Preparation and characterization, Polymer Degradation and Stability, 91 (2006) 2198-2204.

[22] D. Saravanan, T. Gomathi, P.N. Sudha, Sorption studies on heavy metal removal using chitin/bentonite biocomposite, International Journal of Biological Macromolecules, 53 (2013) 67-71.

[23] M. Darder, M. Colilla, E. Ruiz-Hitzky, Chitosan-clay nanocomposites: application as electrochemical sensors, Applied Clay Science, 28 (2005) 199-208.

[24] E. Günister, D. Pestreli, C.H. Ünlü, O. Atıc1, N. Güngör, Synthesis and characterization of chitosan-MMT biocomposite systems, Carbohydrate Polymers, 67 (2007) 358-365.

[25] X. Wang, Y. Du, J. Luo, J. Yang, W. Wang, J.F. Kennedy, A novel biopolymer/rectorite nanocomposite with antimicrobial activity, Carbohydrate Polymers, 77 (2009) 449-456.

[26] K. Zhang, J. Xu, K.Y. Wang, L. Cheng, J. Wang, B. Liu, Preparation and characterization of chitosan nanocomposites with vermiculite of different modification, Polymer Degradation and Stability, 94 (2009) 2121-2127.

[27] A.R. Nesic, S.J. Velickovic, D.G. Antonovic, Characterization of chitosan/montmorillonite membranes as adsorbents for Bezactiv Orange V-3R dye, Journal of Hazardous Materials, 209-210 (2012) 256-263.

[28] M. Jaber, T. Georgelin, H. Bazzi, F. Costa-Torro, J.-F. Lambert, Selectivities in Adsorption and Peptidic Condensation in the (Arginine and Glutamic

Acid)/Montmorillonite Clay System J. Phys. Chem. C, 118 (2014) 25447-25455.

[29] M.K. Jaber, S. ; Zhou, C-H. , Synthesis of Some Clay Minerals, in: F. Bergaya, G. Lagaly (Eds.) Handbook of Clay Science, Elsevier, Amsterdam, 2013, pp. 223-242. [30] D. Zhang, C.-H. Zhou, C.-X. Lin, D.-S. Tong, W.-H. Yu, Synthesis of clay minerals, Applied Clay Science, 50 (2010) 1-11.

[31] K. El Adraa, T. Georgelin, J.-F. Lambert, A.-R. Al-Rabaa, F. Jaber, F. Tielens, M. Jaber, Montmorillonite-Cysteine Composites for Heavy Metal Cation Complexation : a Combined Experimental and Theoretical Study,, Chemical Engeneering Journal, (2016). [32] M. Jaber, J. Miehe-Brendle, R.L. Dred, Mercaptopropyl Al-Mg phyllosilicate: Synthesis and characterization by XRD, IR, and NMR, Chemistry Letters, 31 (2002) 954-955.

[33] P. Monvisade, P. Siriphannon, Chitosan intercalated montmorillonite: Preparation, characterization and cationic dye adsorption, Applied Clay Science, 42 (2009) 427-431. [34] S. Kittinaovarat, P. Kansomwan, N. Jiratumnukul, Chitosan/modified montmorillonite beads and adsorption Reactive Red 120, Applied Clay Science, 48 (2010) 87-91.

[35] M. Jaber, J. Miehe-Brendle, Synthesis, characterization and applications of $2: 1$ phyllosilicates and organophyllosilicates: Contribution of fluoride to study the octahedral sheet, Microporous and Mesoporous Materials, 107 (2008) 121-127. [36] M. Jaber, J. Miehe-Brendle, L. Delmotte, R. Le Dred, New range of Al-Mg organoclays with tailored hydrophobicity: incorporation of fluoride as a local probe to study the octahedral character, Microporous and Mesoporous Materials, 65 (2003) 155 163.

[37] M. Jaber, J. Miehe-Brendle, M. Roux, J. Dentzer, R. Le Dred, J.L. Guth, A new Al,Mg-organoclay, New Journal of Chemistry, 26 (2002) 1597-1600. 
[38] J.-C. Gallego, M. Jaber, J. Miehe-Brendle, C. Marichal, Synthesis of new lamellar inorganic-organic talc-like hybrids, New Journal of Chemistry, 32 (2008) 407-412.

[39] M. Jaber, J. Miehe-Brendle, L. Delmotte, R. Le Dred, Formation of organoclays by a one step synthesis, Solid State Sciences, 7 (2005) 610-615.

[40] L. Wang, J. Zhang, A. Wang, Removal of methylene blue from aqueous solution using chitosan-g-poly(acrylic acid)/montmorillonite superadsorbent nanocomposite, Colloids and Surfaces A: Physicochemical and Engineering Aspects, 322 (2008) 47-53. [41] F. Fournier, L. de Viguerie, S.J. Balme, Jean-Marc;, P. Walter, M. Jaber, Physicochemical characterization of lake pigments based on montmorillonite and carminic acid, Applied Clay Science, (2016) 12-17.

[42] V. Thangaraj, J. Bussiere, J.-M. Janot, M. Bechelany, M. Jaber, S. Subramanian, P. Miele, S. Balme, Fluorescent Quenching of Sulforhodamine dye over Graphene Oxide and Boron Nitride like Graphene, , European Journal of Inorganic Chemistry, 13-14 (2016) 2125-2130.

[43] S. Maisanaba, S. Pichardo, M. Puerto, D. Gutiérrez-Praena, A.M. Cameán, A. Jos, Toxicological evaluation of clay minerals and derived nanocomposites: A review, Environmental Research, 138 (2015) 233-254.

[44] P. Sathishkumar, M. Arulkumar, T. Palvannan, Utilization of agro-industrial waste Jatropha curcas pods as an activated carbon for the adsorption of reactive dye Remazol Brilliant Blue R (RBBR), Journal of Cleaner Production, 22 (2012) 67-75.

[45] T. Mechichi, N. Mhiri, S. Sayadi, Remazol Brilliant Blue R decolourization by the laccase from Trametes trogii, Chemosphere, 64 (2006) 998-1005.

[46] M.A.M. Salleh, D.K. Mahmoud, W.A.W.A. Karim, A. Idris, Cationic and anionic dye adsorption by agricultural solid wastes: A comprehensive review, Desalination, 280 (2011) 1-13.

[47] M.M.F. Silva, M.M. Oliveira, M.C. Avelino, M.G. Fonseca, R.K.S. Almeida, E.C. Silva Filho, Adsorption of an industrial anionic dye by modified-KSF-montmorillonite: Evaluation of the kinetic, thermodynamic and equilibrium data, Chemical Engineering Journal, 203 (2012) 259-268.

[48] J. Madejová, B. Arvaiová, P. Komadel, FTIR spectroscopic characterization of thermally treated $\mathrm{Cu} 2+, \mathrm{Cd} 2+$, and $\mathrm{Li}+$ montmorillonites, Spectrochimica Acta Part A: Molecular and Biomolecular Spectroscopy, 55 (1999) 2467-2476.

[49] B. Tyagi, C.D. Chudasama, R.V. Jasra, Determination of structural modification in acid activated montmorillonite clay by FT-IR spectroscopy, Spectrochimica Acta Part A: Molecular and Biomolecular Spectroscopy, 64 (2006) 273-278.

[50] Z. Li, W.-T. Jiang, H. Hong, An FTIR investigation of

hexadecyltrimethylammonium intercalation into rectorite, Spectrochimica Acta Part A: Molecular and Biomolecular Spectroscopy, 71 (2008) 1525-1534.

[51] W.A. Zhang, D.Z. Chen, H.Y. Xu, X.F. Shen, Y.E. Fang, Influence of four different types of organophilic clay on the morphology and thermal properties of polystyrene/clay nanocomposites prepared by using the $\gamma$-ray irradiation technique, European Polymer Journal, 39 (2003) 2323-2328.

[52] J. Madejová, J. Bujdák, M. Janek, P. Komadel, Comparative FT-IR study of structural modifications during acid treatment of dioctahedral smectites and hectorite, Spectrochimica Acta Part A: Molecular and Biomolecular Spectroscopy, 54 (1998) 1397-1406.

[53] C. Paluszkiewicz, M. Holtzer, A. Bobrowski, FTIR analysis of bentonite in moulding sands, Journal of Molecular Structure, 880 (2008) 109-114.

[54] A. Domard, M. Rinaudo, Preparation and characterization of fully deacetylated chitosan, International Journal of Biological Macromolecules, 5 (1983) 49-52. 
[55] S. Beil, A. Schamberger, W. Naumann, S. Machill, K.-H. van Pée, Determination of the degree of N-acetylation (DA) of chitin and chitosan in the presence of water by first derivative ATR FTIR spectroscopy, Carbohydrate Polymers, 87 (2012) 117-122. [56] M.R. Kasaai, A review of several reported procedures to determine the degree of $\mathrm{N}$-acetylation for chitin and chitosan using infrared spectroscopy, Carbohydrate Polymers, 71 (2008) 497-508.

[57] C. Paluszkiewicz, E. Stodolak, M. Hasik, M. Blazewicz, FT-IR study of montmorillonite-chitosan nanocomposite materials, Spectrochimica Acta Part A: Molecular and Biomolecular Spectroscopy, 79 (2011) 784-788.

[58] F.A. López, A.L.R. Mercê, F.J. Alguacil, A. López-Delgado, A kinetic study on the thermal behaviour of chitosan, J Therm Anal Calorim, 91 (2008) 633-639.

[59] R. Laus, T.G. Costa, B. Szpoganicz, V.T. Fávere, Adsorption and desorption of $\mathrm{Cu}(\mathrm{II}), \mathrm{Cd}(\mathrm{II})$ and $\mathrm{Pb}(\mathrm{II})$ ions using chitosan crosslinked with epichlorohydrintriphosphate as the adsorbent, Journal of Hazardous Materials, 183 (2010) 233-241. [60] W. Tan, Y. Zhang, Y.-s. Szeto, L. Liao, A novel method to prepare chitosan/montmorillonite nanocomposites in the presence of hydroxy-aluminum oligomeric cations, Composites Science and Technology, 68 (2008) 2917-2921. [61] R. Celis, M.A. Adelino, M.C. Hermosín, J. Cornejo, Montmorillonite-chitosan bionanocomposites as adsorbents of the herbicide clopyralid in aqueous solution and soil/water suspensions, Journal of Hazardous Materials, 209-210 (2012) 67-76.

[62] M.R. Kasaai, Determination of the degree of N-acetylation for chitin and chitosan by various NMR spectroscopy techniques: A review, Carbohydrate Polymers, 79 (2010) 801-810.

[63] M.R. Kasaai, Various Methods for Determination of the Degree of N-Acetylation of Chitin and Chitosan: A Review, Journal of Agricultural and Food Chemistry, 57 (2009) 1667-1676.

[64] T.A. Khan, K.K. Peh, H.S. Ch'ng, Reporting degree of deacetylation values of chitosan: the influence of analytical methods, J Pharm Pharm Sci, 5 (2002) 205-212. [65] I.K.D. Dimzon, T.P. Knepper, Degree of deacetylation of chitosan by infrared spectroscopy and partial least squares, International Journal of Biological Macromolecules, 72 (2015) 939-945.

[66] I.S. Lima, C. Airoldi, A thermodynamic investigation on chitosan-divalent cation interactions, Thermochimica Acta, 421 (2004) 133-139.

[67] S. Garrison, P. Sung-Ho, Molecular Modeling of Clay Mineral Structure and Surface Chemistry, in: Handbook of Layered Materials, CRC Press, 2004.

[68] R. Ait-Akbour, P. Boustingorry, F. Leroux, F. Leising, C. Taviot-Guého, Adsorption of PolyCarboxylate Poly(ethylene glycol) (PCP) esters on Montmorillonite (Mmt): Effect of exchangeable cations $(\mathrm{Na}+\mathrm{Mg} 2+$ and $\mathrm{Ca} 2+)$ and $\mathrm{PCP}$ molecular structure, Journal of Colloid and Interface Science, 437 (2015) 227-234.

[69] L. Zhou, H. Chen, X. Jiang, F. Lu, Y. Zhou, W. Yin, X. Ji, Modification of montmorillonite surfaces using a novel class of cationic gemini surfactants, Journal of Colloid and Interface Science, 332 (2009) 16-21.

[70] B.R.d. Santos, F.B. Bacalhau, T.d.S. Pereira, C.F. Souza, R. Faez, ChitosanMontmorillonite microspheres: A sustainable fertilizer delivery system, Carbohydrate Polymers, 127 (2015) 340-346.

[71] Y.n. Liu, C. Dong, H. Wei, W. Yuan, K. Li, Adsorption of levofloxacin onto an iron-pillared montmorillonite (clay mineral): Kinetics, equilibrium and mechanism, Applied Clay Science, 118 (2015) 301-307.

[72] R.J. Samuels, Solid state characterization of the structure of chitosan films, Journal of Polymer Science: Polymer Physics Edition, 19 (1981) 1081-1105. 
[73] I. Younes, M. Rinaudo, Chitin and Chitosan Preparation from Marine Sources. Structure, Properties and Applications, Marine Drugs, 13 (2015) 1133-1174.

[74] S. Sinha Ray, 4 - Processing and Characterization, in: Clay-Containing Polymer Nanocomposites, Elsevier, Amsterdam, 2013, pp. 67-170.

[75] S. Pavlidou, C.D. Papaspyrides, A review on polymer-layered silicate nanocomposites, Progress in Polymer Science, 33 (2008) 1119-1198.

[76] S. Sinha Ray, 3 - Structure and Morphology Characterization Techniques, in: Clay-Containing Polymer Nanocomposites, Elsevier, Amsterdam, 2013, pp. 39-66. [77] M.O. Machado, E.C.N. Lopes, K.S. Sousa, C. Airoldi, The effectiveness of the protected amino group on crosslinked chitosans for copper removal and the thermodynamics of interaction at the solid/liquid interface, Carbohydrate Polymers, 77 (2009) 760-766.

[78] K.V. Harish Prashanth, F.S. Kittur, R.N. Tharanathan, Solid state structure of chitosan prepared under different N-deacetylating conditions, Carbohydrate Polymers, 50 (2002) 27-33.

[79] H. Ennajih, R. Bouhfid, E.M. Essassi, M. Bousmina, A. El Kadib, Chitosanmontmorillonite bio-based aerogel hybrid microspheres, Microporous and Mesoporous Materials, 152 (2012) 208-213.

[80] S.L. Swartzen-Allen, E. Matijevic, Surface and colloid chemistry of clays, Chemical Reviews, 74 (1974) 385-400.

[81] M. Rinaudc, G. Pavlov, J. Desbrières, Solubilization of Chitosan in Strong Acid Medium, International Journal of Polymer Analysis and Characterization, 5 (1999) 267 276.

[82] M. Kosmulski, Surface charging and points of zero charge, CRC Press, 2010. [83] J.d.O. Marques Neto, C.R. Bellato, J.L. Milagres, K.D. Pessoa, E.S.d. Alvarenga, Preparation and evaluation of chitosan beads immobilized with Iron(III) for the removal of As(III) and As(V) from water, Journal of the Brazilian Chemical Society, 24 (2013) 121-132.

[84] P. Baskaralingam, M. Pulikesi, V. Ramamurthi, S. Sivanesan, Modified hectorites and adsorption studies of a reactive dye, Applied Clay Science, 37 (2007) 207-214. [85] C. Montagner, M. Bacci, S. Bracci, R. Freeman, M. Picollo, Library of UV-VisNIR reflectance spectra of modern organic dyes from historic pattern-card coloured papers, Spectrochimica Acta Part A: Molecular and Biomolecular Spectroscopy, 79 (2011) 1669-1680.

[86] M.E. Roca Jalil, M. Baschini, E. Rodríguez-Castellón, A. Infantes-Molina, K. Sapag, Effect of the Al/clay ratio on the thiabendazol removal by aluminum pillared clays, Applied Clay Science, 87 (2014) 245-253.

[87] M.A. Ahmad, S.G. Herawan, A.A. Yusof, Equilibrium, Kinetics, and Thermodynamics of Remazol Brilliant Blue R Dye Adsorption onto Activated Carbon Prepared from Pinang Frond, ISRN Mechanical Engineering, 2014 (2014) 7. [88] X. Jiang, Y. Sun, L. Liu, S. Wang, X. Tian, Adsorption of C.I. Reactive Blue 19 from aqueous solutions by porous particles of the grafted chitosan, Chemical Engineering Journal, 235 (2014) 151-157.

[89] L. Wang, J. Zhang, A. Wang, Fast removal of methylene blue from aqueous solution by adsorption onto chitosan-g-poly (acrylic acid)/attapulgite composite, Desalination, 266 (2011) 33-39.

[90] M. Auta, B.H. Hameed, Chitosan-clay composite as highly effective and low-cost adsorbent for batch and fixed-bed adsorption of methylene blue, Chemical Engineering Journal, 237 (2014) 352-361. 
[91] A. Mirmohseni, M.S. Seyed Dorraji, A. Figoli, F. Tasselli, Chitosan hollow fibers as effective biosorbent toward dye: Preparation and modeling, Bioresource Technology, 121 (2012) 212-220.

[92] S. Lagergren, B.K. Svenska, On the theory of so-called adsorption of materials, R. Swed. Acad. Sci. Doc, Band, 24 (1898) 1-13.

[93] Y.S. Ho, G. McKay, Pseudo-second order model for sorption processes, Process Biochemistry, 34 (1999) 451-465.

[94] Y. Peng, D. Chen, J. Ji, Y. Kong, H. Wan, C. Yao, Chitosan-modified palygorskite: Preparation, characterization and reactive dye removal, Applied Clay Science, 74 (2013) 81-86.

[95] A. Vanaamudan, P.P. Sudhakar, Equilibrium, kinetics and thermodynamic study on adsorption of reactive blue-21 and reactive red-141 by chitosan-organically modified nanoclay (Cloisite 30B) nano-bio composite, Journal of the Taiwan Institute of Chemical Engineers, 55 (2015) 145-151.

[96] Q. Liu, B. Yang, L. Zhang, R. Huang, Adsorption of an anionic azo dye by crosslinked chitosan/bentonite composite, International Journal of Biological Macromolecules, 72 (2015) 1129-1135.

[97] I. Langmuir, The adsorption of gases on plane surfaces of glass, mica and platinum, Journal of the American Chemical Society, 40 (1918) 1361-1403.

[98] H.M.F. Freündlich, Über die Adsorption in Lösungen, Zeitschrift fur. Physikalische Chemie (Leipzig), A 57 (1907) 85.

[99] S. Karimifard, M.R. Alavi Moghaddam, Enhancing the adsorption performance of carbon nanotubes with a multistep functionalization method: Optimization of Reactive Blue 19 removal through response surface methodology, Process Safety and Environmental Protection, 99 (2016) 20-29.

[100] M. Hasan, A.L. Ahmad, B.H. Hameed, Adsorption of reactive dye onto crosslinked chitosan/oil palm ash composite beads, Chemical Engineering Journal, 136 (2008) 164-172.

[101] T.P. Hough, Trends in Solar Energy Research, Nova Science Publishers, 2006. [102] K. Chen, J. Li, J. Li, Y. Zhang, W. Wang, Synthesis and characterization of $\mathrm{TiO} 2-$ montmorillonites doped with vanadium and/or carbon and their application for the photodegradation of sulphorhodamine B under UV-vis irradiation, Colloids and Surfaces A: Physicochemical and Engineering Aspects, 360 (2010) 47-56.

[103] J. Alin, M. Rubino, R. Auras, In situ characterization of organo-modified and unmodified montmorillonite aqueous suspensions by UV-visible spectroscopy, Journal of Colloid and Interface Science, 456 (2015) 155-160.

[104] L. Iturriaga, I. Olabarrieta, A. Castellan, C. Gardrat, V. Coma, Active naringinchitosan films: Impact of UV irradiation, Carbohydrate Polymers, 110 (2014) 374-381. [105] A.L. Andrady, A. Torikai, T. Kobatake, Spectral sensitivity of chitosan photodegradation, Journal of Applied Polymer Science, 62 (1996) 1465-1471. 


\section{SUPPLEMENTARY MATERIAL}

Table SM1. Quantities of chitosan and KSF-Na on the beads based on CHN data

Figure SM1. Zero charge point measurements for the samples of (a) KSF-Na, (b) CS,

(c) KSF-CTS-1\%, (d) KSF-CTS-5\%, (e) KSF-CTS 15\% and (f) KSF-CTS-25\%.

Figure SM2. Molecular absorption spectra of Remazol Blue at $15 \mathrm{mg} \mathrm{L}^{-1}$ from different pHs at room temperature.

Figure SM3. Adjustment sorption data applied to the models of (i) pseudo-first and (ii) pseudo-second order for Remazol blue kinetics on (a) CS, (b) KSF CTS-1\%, (c) KSFCTS-5\%, (d) KSF-CTS-15\% and (e) CTS-KSF-25\% $500 \mathrm{mg} \mathrm{L}^{-1}$, pH 3 and $298 \pm 1 \mathrm{~K}$.

Figure SM4. Adjustment of the Remazol blue sorption isotherms applied to Langmuir adsorption model for the samples (a) CS, (b) KSF-CTS-1\%, (c) KSF-CTS-5\%, (d) KSFCTS-15\% and (e) CTS-KSF-25\% at 100-1600 $\mathrm{mg} \mathrm{L}^{-1}, \mathrm{pH} 3$ and $298 \mathrm{~K} \pm 1 \mathrm{~K}$.

Figure SM5. Adjustment of the Remazol blue sorption isotherms applied to Freundlich model for the samples (a) CS, (b) KSF-CTS-1\%, (c) KSF-CTS-5\%, (d) KSF-CTS-15\% and (e) CTS-KSF-25\% at 100-1600 $\mathrm{mg} \mathrm{L}^{-1}, \mathrm{pH} 3$ and $298 \mathrm{~K} \pm 1 \mathrm{~K}$.

Figure SM6. i) Infrared absorption spectra and ii) XRD patterns for the samples after dye sorption (a) CS, (b) KSF-CTS-1\%/RB, (c) KSF-CTS-5\%/RB, (d) CTS-KSF15\%/RB, (e) KSF-CTS-25\%/RB and (f) RB dye. Abbreviations: Mt. montmorillonite; M, muscovite; Q, quartz; Qt, chitosan.

Figure SM7. UV-Visible solid spectra for the samples (a) CS, (b) KSF-Na, (c) RB, (d) CS-RB, (e) KSF-CTS-1\%-RB, (f) KSF, CTS-5\%-RB, (g) KSF-CTS-15\%-RB and (h) KSF-CTS-25\%-RB. 